\title{
"E por um profeta ele foi guardado": tradições e profetismo em Os 12,12-15
}

\author{
"And by a prophet he was kept": \\ traditions and prophetism in Hos. 12,12-15
}

Ygor Almeida de Carvalho Silva

\section{Resumo}

O presente artigo se dedica ao estudo de Os 12,12-15, uma perícope rica em detalhes que chamam a atenção do leitor atento: uma mensagem que denuncia a falsidade e a nulidade de uma religião associada a práticas pecaminosas (v.12); uma referência ao Patriarca Jacó, cuja imagem moral no v.13 é ponto de amplo debate entre os intérpretes (se seria positiva ou negativa); os dois relatos de origem de Israel (genealógica e vocacional) encontrando-se lado a lado em pleno séc. VIII a.C. (vv.13-14); a(s) figura(s) anônima(s) de um ou dois profetas no v.14; e uma advertência de condenação iminente em consequência da infidelidade e da desobediência prevalecentes no Reino do Norte (v.15). Os 12,12-15 é um texto em prosa recheado de elementos da poesia hebraica. Esta pesquisa segue os passos da exegese científica e culmina num comentário e em considerações finais onde são feitas aplicações de natureza teológico-pastoral, sem qualquer pretensão de esgotar os temas envolvidos.

Palavras-chave: Oseias. Tradições. Profeta. Êxodo.

\begin{abstract}
This article is dedicated to the study of Hos. 12,12-15, a pericope rich in details that catch the attention of the attentive reader: a message that denounces the falsehood and nullity of a religion associated with sinful practices (v.12); a reference to Patriarch Jacob, whose moral image in v.13 is a point of wide debate among the interpreters (whether it would be positive or negative); the two accounts of Israel's origin (genealogical and vocational) meeting side by
\end{abstract}


side in the century VIII BC (vv.13-14); the anonymous figure (s) of one or two prophets in v.14; and a warning of impending doom as a result of the infidelity and disobedience prevalent in the Northern Kingdom (v.15). Hos. 12.12-15 is a prose text filled with elements of Hebrew poetry. This research follows in the footsteps of scientific exegesis and culminates in a comment and final considerations where applications of a theological-pastoral nature are made, without any intention of exhausting the issues involved.

Keywords: Hosea. Traditions. Prophet. Exodus.

\section{Introdução}

A história de Oseias é uma das mais intrigantes de toda a Bíblia Sagrada. Como poucos profetas, ele precisou encarnar sua mensagem (Is 20,3; Ez 5,4-7; At 21,10-11), e teve de fazê-lo de um modo bastante incomum: casando-se com uma prostituta (Os 1,2-3). Pode-se imaginar o escândalo que seria para uma comunidade de fé ou para a sociedade civil, se um líder religioso ou um famoso pregador contraísse matrimônio com uma garota de programa. Mas foi a partir deste relacionamento inusitado e conturbado, narrado nos primeiros três primeiros capítulos de Oseias, que vem a maior parte das lições dos outros onze capítulos, cujo tema central é o amor incondicional de $\mathrm{YHWH}$, que tenta salvar seu povo do adultério espiritual, cometido principalmente na idolatria e na violência. Na passagem de Os 12,12-15, encontra-se uma das mais belas mensagens deste livro.

Oseias foi um profeta do Reino do Norte, e ele situa o seu ministério como tendo ocorrido quando Jeroboão II era o seu monarca, e quando Ozias, Joatão, Acaz e Ezequias reinaram em Judá (Os 1,1). Pelo período em que estes reis governaram, é possível datar o ofício profético de Oseias como tendo-se desenvolvido, na segunda metade do séc. VIII a.C. Naquela época, o Império Assírio estava em franca expansão, conquistando vários territórios do Oriente Médio, Mesopotâmia e rumando para o Egito. Oseias foi um contemporâneo mais jovem de Amós, profeta no Reino do Sul. No início deste período, Israel experimentou um momento de prosperidade, e depois de gradativa decadência. Foi neste tempo que houve a guerra siro-efraimita, quando Síria e Israel formaram uma coalisão militar para tentar resistir a Assíria e conquistar Judá - 
ambas tentativas infrutíferas (2Rs $15,19-20.29) .{ }^{1}$ E foi neste período de incerteza religiosa, política e econômica que Oseias profetizou.

Em algumas traduções bíblicas, a perícope de Os 12,12-15 é 11,12-12,14, mas para esta pesquisa, segue-se o Texto Massorético (TM), onde a passagem se encontra mesmo em 12,12-15. Esta perícope contém alguns pontos muito relevantes, que serão explorados neste artigo: a) Como a religião de Israel tornara-se tão vazia, até ao ponto em que seu culto seria totalmente aniquilado (v.12)? b) Seria a figura de Jacó positiva ou negativa na perspectiva de Os 12,13 ? c) Se as tradições dos patriarcas e do êxodo só teriam sido reunidas no séc. V a.C., como é que elas se encontram lado a lado em Os 12,13-14? d) Os 12,14 trata de dois profetas ou de um só? E quem seria(m) ele(s)? e) Seria YHWH um Deus irascível e impaciente, que destruiria seu povo por vingança, ou será que a destruição iminente era a consequência das próprias más escolhas da nação (v.15)?

\section{Tradução e Segmentação}

\begin{tabular}{|c|c|c|}
\hline $12 \mathrm{a}$ & 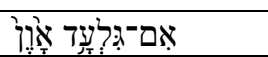 & Visto que Galaad é uma iniquidade, \\
\hline $12 \mathrm{~b}$ & 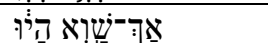 & apenas um vazio eles são; \\
\hline $12 \mathrm{c}$ & 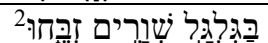 & em Guilgal sacrificam touros, \\
\hline
\end{tabular}

1 WOLFF, H. W., Hosea, p. xxi; MCCOMISKEY, T. E., The Minor Prophets, p. 1-3; HUBBARD, D. A., Oseias, p. 26-29; ALONSO SCHÖKEL, L.; SICRE DIAZ, J. L., Profetas II, p. 887-888; FRETHEIM, T. E., Reading Hosea-Micah, p. 8-10; RÖMER, T., Oseias, p. 470-471; NICHOL, F. D., Isaías a Malaquias, p. 6-7, 975-976; DEARMAN, J. A., The Book of Hosea, p. 3-6; PENTIUC, E. J., Long-Suffering Love, p. 1-4; MACKAY, J. L., Oseias, p. 8-17.

${ }^{2}$ Detalhe que chama a atenção: Diferentemente da maior parte do texto da Bíblia Hebraica, onde o verbo está no início das orações, nesta passagem, alguns dos verbos se encontram no final:

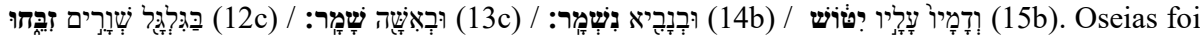
um profeta do Reino do Norte. Para Rendsburg, há diferenças entre o hebraico bíblico padrão, que mais aparece no AT, próprio de Judá, o Reino do Sul; e o dialeto nortista, o qual ele chama de "hebraico israeliano" (RENDSBURG, G. A., Linguistic Variation and the Foreign Factor in the Hebrew Bible, p. 177; RENDSBURG, G. A., A Comprehensive Guide to the Israelian Hebrew, p. 5). Ainda segundo Rendsburg, há traços deste dialeto nortista em todo o livro de Oseias (RENDSBURG, G. A., A Comprehensive Guide to the Israelian Hebrew, p. 8). Uma das marcas do hebraico bíblico padrão é a ordem das palavras numa oração da seguinte maneira: verbo - sujeito - objeto (DEL BARCO DEL BARCO, F. J., Sintaxes Verbal en los Profetas Menores Preexílicos, p. 13). E uma das marcas do "hebraico israeliano" seria a colocação do verbo numa posição posterior dentro da oração. 


\begin{tabular}{|c|c|c|}
\hline $12 \mathrm{~d}$ & 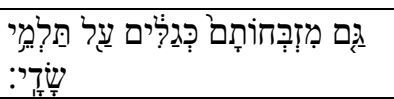 & $\begin{array}{l}\text { também seus altares serão como montões } \\
\text { de pedras }{ }^{3} \text { sobre os sulcos do campo. }{ }^{4}\end{array}$ \\
\hline $13 a$ & 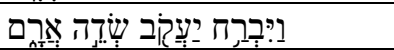 & Fugiu Jacó para o campo de Aram, \\
\hline $13 b$ & 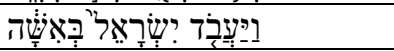 & serviu Israel por uma mulher, \\
\hline $13 \mathrm{c}$ & ) & $\begin{array}{l}\text { e por uma mulher ele guardou (um } \\
\text { rebanho). }\end{array}$ \\
\hline $14 \mathrm{a}$ & 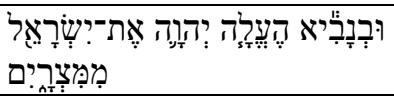 & $\begin{array}{l}\text { Por um profeta YHWH fez subir Israel } \\
\text { do Egito, }\end{array}$ \\
\hline $14 \mathrm{~b}$ & 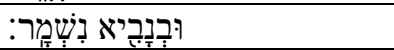 & e por um profeta ele foi guardado. \\
\hline $15 \mathrm{a}$ & 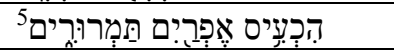 & Provocou a ira ${ }^{6}$ Efraim amargamente, ${ }^{7}$ \\
\hline $15 b$ & 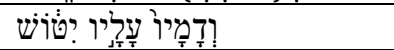 & seu sangue derramará sobre $\mathrm{si}^{8}{ }^{8}$ \\
\hline
\end{tabular}

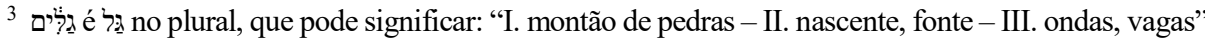
(DAVIDSON, B., לג, p. 138); "1. Montão, monte, acervo; monte de entulhos, escombros, ruínas; cerca (...) 2. Onda, vaga, quebra-mar. Pl. Vagalhão, marulho, marulhada” (ALONSO SCHÖKEL, L., לֵֵ, p.

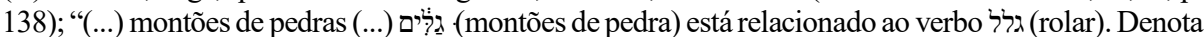
aquilo que vai rolando junto, tal como as ondas do mar (Jr 5:22) ou montões de pedras (Is 25:2). Haja vista que estes 'montões' estão sobre os 'sulcos dos campos', somos inclinados a pensar em montões de pedras." (MCCOMISKEY, T. E., The Minor Prophets, p. 208, 210).

4 שָָָׁ é uma forma poética de "I. planície, campina (...) II. campo, porção de terra cultivada; III. colet.: os campos, o país; IV. país, território." (DAVIDSON, B., שָָָׁ p. 702); "Campo, com

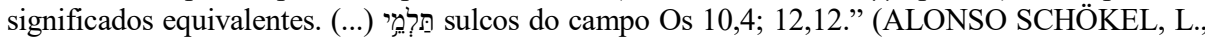

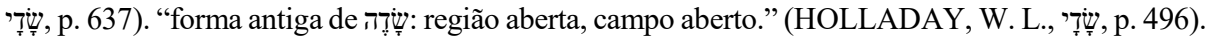
${ }^{5}$ De acordo com o aparato crítico da Bíblia Hebraica Stuttgartensia (p. 1006), na oração 15a ("Provocou a ira Efraim amargamente"), a Septuaginta (LXX) e a versão siríaca Peshita

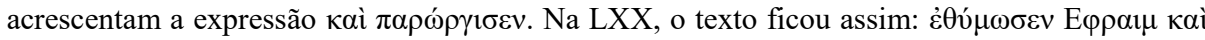
$\pi \alpha \rho \omega ́ \rho \gamma \imath \sigma \varepsilon v$ ("Efraim irritou e provocou a ira").

${ }^{6}$ No hifil, o verbo

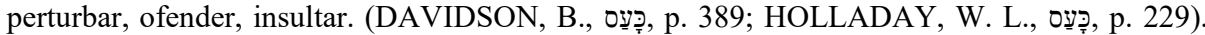
Para que a tradução ficasse mais coerente com a sintaxe da língua portuguesa, preferiu-se "provocar a ira". Alonso-Schökel esclarece que o verbo ợ no hifil é frequente "na tradição deuteronomista, com sujeito povo e complemento Deus" (ALONSO-SCHÖKEL, L., ככָכָ p. p. 323).

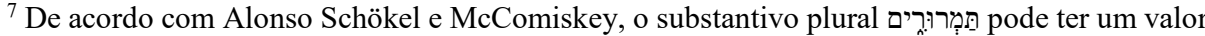

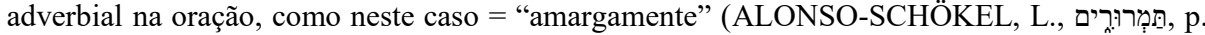
705; MCCOMISKEY, T. E., The Minor Prophets, p. 211).

${ }^{8}$ Lit.: "ele derramará os sangues dele sobre ele". Quem é o sujeito desta oração? As traduções Almeida Revista e Atualizada $2^{\mathrm{a}}$ Ed., Bíblia de Jerusalém, Nova Versão Internacional, Nova Tradução da CNBB, Nova Almeida Atualizada e Nova Tradução Ecumênica da Bíblia entendem que é o Senhor. Contudo, McComiskey compreende que seja Efraim, pois ele é o sujeito explícito da oração imediatamente anterior (MCCOMISKEY, T. E., The Minor Prophets, p. 208). Conquanto seja difícil chegar a uma conclusão inquestionável neste caso, entendemos que a opção gramaticalmente mais precisa seria esta última. Daí a proposta de tradução: "seu sangue derramará sobre si"; uma vez também que não é correto dizer em português "seus sangues". 


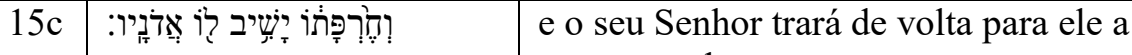 sua vergonha.}

\section{Críticas Literária ou da Constituição do Texto}

Andersen e Freedman sugerem não somente a unidade da perícope dos vv. 12-15, como de todo o cap. 12 de Oseias. ${ }^{9}$ De acordo com eles, uma forte evidência desta unidade é a correspondência entre os vv. 3 e $15 .{ }^{10}$ Três são os

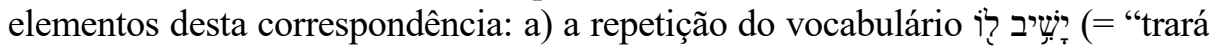
de volta para ele", sentido de retribuição); ${ }^{11}$ b) a sequência das preposições עַ e ? , recorrente em Oseias, notavelmente em ambos os vv. 3 e 15; e c) a declaração do v. 3 é seguida pela primeira informação sobre Jacó (vv.4-5), e a declaração do v.15 segue a segunda informação sobre o mesmo patriarca (v.13). ${ }^{12}$ Wolff também acredita nesta unidade de Os $12,{ }^{13}$ e indica outra evidência:

A palavra-chave 'falsidade' (מ̣רָ) no v.1 - encontrada somente no cap. 12 - ocorre novamente no v.8 e permanece o assunto dominante até $\mathrm{o}$ v.15. Ali, a provocação e o abuso amargos de Efraim são expressos pela

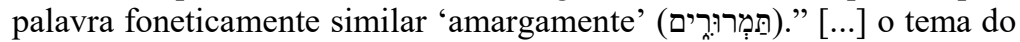
engano é desenvolvido com referência ao espírito de barganha de Efraim (vv.2.8) e Gilgal (v.12). ${ }^{14}$

Lima, que vai na mesma direção, explana o seguinte:

O c. 12 de Oseias apresenta-se claramente como uma unidade, distinto tanto do que o precede como do que o segue. Frente a Os 11,1-8, oráculo de salvação para Israel, mostra-se independente enquanto apresenta agora o pecado de Efraim numa perspectiva própria, qual seja a da culpa como fraude e traição contra Deus. Já o primeiro versículo aponta para este tema, que será desenvolvido sob variados pontos de vista no decorrer

\footnotetext{
${ }^{9}$ ANDERSEN, F. I.; FREEDMAN, D. N., Hosea, p. 622.

${ }^{10}$ ANDERSEN, F. I.; FREEDMAN, D. N., Hosea, p. 622.

${ }^{11}$ WOLFF, H. W., Hosea, p. 208, 217, aponta nesta mesma direção.

12 ANDERSEN, F. I.; FREEDMAN, D. N., Hosea, p. 622. Sobre o Patriarca Jacó como fator de unidade de Os 12, ver também FRETHEIM, T. E., Reading Hosea-Micah, p. 68.

${ }^{13}$ WOLFF, H. W., Hosea, p. 207-208.

${ }^{14}$ WOLFF, H. W., Hosea, p. 208. Sobre a unidade literária de todo o capítulo 12, ver também SIMIAN-YOFRE, H., El Deserto de los Dioses, p. 155. À p. 163, Simian-Yofre pondera que a única exceção a esta unidade do capítulo talvez seja o v.1cd, por causa da menção honrosa a Judá, provavelmente porque seja referido negativamente no v. 3 .
} 
do capítulo. Em Os 13,1 inicia-se uma nova acusação, diferente daquela desenrolada no c. 12, distinguindo-se nesse sentido desta última. Podemos assim delimitar a unidade, que se inicia em Os 12,1 e é concluída em Os 12,15. [...] o v.1a, trazendo a palavra mirmāh, introduz o tema da fraude, que no v.15a é concluído com a interpretação da culpa de Israel exatamente como fraude contra Deus. [...] O c. 12 de Oseias constitui-se assim numa unidade sob o ponto de vista temático, para a qual concorrem também elementos formais. ${ }^{15}$

A perícope de Os 12,12-15 traz uma mensagem de denúncia e juízo para Israel, sucedendo os vv.10-11, cujo conteúdo é uma profecia de restauração. Nos vv.10-11, YHWH fala em primeira pessoa. Já dentro da perícope de 12,1215, o texto aparece formulado como o profeta falando de YHWH em terceira pessoa (vv.14-15). O v.12 inicia com a partícula אִ, que geralmente é condicional, mas que também pode ter valor causal, como neste caso, significando "Visto que" ou "Já que"16 - introduz um novo pensamento. Os vv.13-14 formam uma unidade retórica:

"Fugiu Jacó para o campo de Aram, serviu Israel por uma mulher e por uma mulher ele guardou (um rebanho).

Por um profeta YHWH fez subir Israel do Egito, e por um profeta ele foi guardado".

A oração 15c encerra a punição: "e o seu Senhor trará de volta para ele a sua vergonha". Encerra também toda a seção do capítulo, que começa com uma denúncia contra Efraim (Os 12,1), e termina com uma condenação contra o mesmo Efraim. Os 13,1a-b já inicia uma nova perícope: "Quando Efraim falava havia um temor..." - percebe-se nitidamente a mudança de assunto. Assim, podemos concluir que há unidade na perícope de Os 12,12-15, correndo o texto de maneira coerente e lógica, sem perturbações.

\section{Críticas da Forma e do Gênero Literário}

\subsection{Estrutura do texto}

O texto de Os 12,12-15 apresenta-se organizado nas seguintes subunidades: v. 12 - Denúncia contra a iniquidade e os sacrifícios vãos; vv. 13-14 - Recordação de dois grandes personagens da história de Israel: Jacó e Moisés, e da bondade de YHWH para com seu povo;

${ }^{15}$ LIMA, M. L. C., Hesed nos Escritos de Oseias, p. 221.

${ }^{16}$ ALONSO SCHÖKEL, L., ạ, p. 60. 
v. 15 - Anúncio de punição da nação por provocar a ira de Deus.

\subsection{Análise estilística}

O texto é escrito num estilo de prosa elevada (que contém elementos de poesia), chamada também de prosa discursiva (que é diferente da prosa

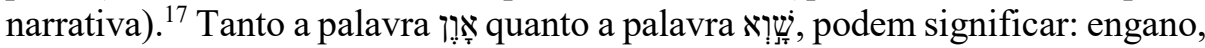
fraude, nulidade, nada, vaidade, iniquidade e perversidade. ${ }^{18}$ Wolff também vê identificação e correspondência entre os dois vocábulos. ${ }^{19}$ Assim, pode-se verificar um paralelismo sinônimo e ao mesmo tempo quiástico no v. 12ab:

\begin{tabular}{|c|c|}
\hline 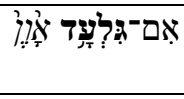 & $\begin{array}{l}\text { Visto que Galaad (sujeito) é (verbo de ligação) uma } \\
\text { iniquidade (predic. suj.), }\end{array}$ \\
\hline 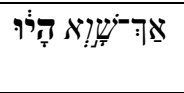 & $\begin{array}{l}\text { apenas um vazio (predic. suj.) eles (sujeito) são (verbo de } \\
\text { ligação); }\end{array}$ \\
\hline
\end{tabular}

Outro elemento poético pode ser constatado também no v.13. A estrutura do tricólon no v.13 é intrincada. O paralelismo de "Jacó" e "Israel" liga a primeira e a segunda linhas, embora a fuga para o campo de Arã e o serviço por uma esposa não configurem um paralelismo. A última e curta linha "por uma mulher ele guardou (um rebanho)" com seu quiasmo com a segunda linha, forma o paralelo com ela. ${ }^{20}$

\begin{tabular}{|c|c|}
\hline 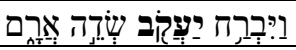 & Fugiu Jacó para o campo de Aram, \\
\hline 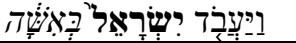 & serviu Israel por uma mulher \\
\hline 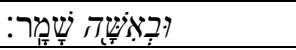 & e por uma mulher ele guardou (um rebanho). \\
\hline
\end{tabular}

\footnotetext{
${ }^{17}$ Pentiuc explica que a poesia dos profetas do $8^{\circ}$ século a.C. difere da poesia do Pentateuco e dos Salmos, e que a prosa deles é diferente daquela encontrada em Deuteronômio, por exemplo. Este estilo de prosa poética, que possui um certo ritmo e características estilísticas, é chamada de prosa-poesia ou prosa elevada. (PENTIUC, E. J., Long-Suffering Love, p. 15). O escritor explana também que a poesia clássica de Isaías e Miqueias é mais bem elaborada do que a de Amós e Oseias (PENTIUC, E. J., Long-Suffering Love, p. 15).

${ }^{18}$ HOLLADAY, W. L., אֶֶ, p. 7; e HOLLADAY, W. L., שֶֶׁ, p. 362; ALONSO SCHÖKEL, L.,

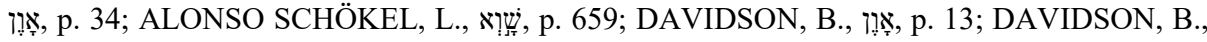

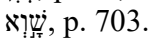

${ }^{19}$ WOLFF, H. W., Hosea, p. 217.

${ }^{20}$ ANDERSEN, F. I.; FREEDMAN, D. N., Hosea, p. 620.
} 
Ainda outra faceta desta prosa elevada aparece entre os vv.3bc e 14. Só que aqui o caso é de um paralelismo antitético entre os dois versículos ${ }^{21}$ um paralelismo sinônimo dentro do v.14:

\begin{tabular}{|c|c|}
\hline 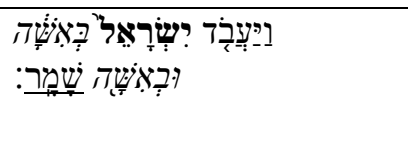 & $\begin{array}{l}\text { serviu Israel por uma mulher } \\
\text { e por uma mulher ele guardou [um } \\
\text { rebanho]. }\end{array}$ \\
\hline 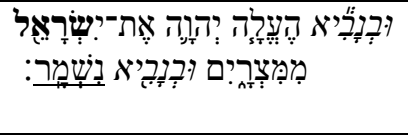 & $\begin{array}{l}\text { Por um profeta YHWH fez subir Israel do } \\
\text { Egito; } \\
\text { e por um profeta ele foi guardado. }\end{array}$ \\
\hline
\end{tabular}

\subsection{Crítica do Gênero Literário}

Pode-se dizer que todo o cap. 12 de Oseias é um oráculo de juízo, ou um $r \underline{i} \underline{b}$ : discurso de processo judicial ou demanda legal. ${ }^{22} \mathrm{O}$ próprio termo rîb

${ }^{21}$ LIMA, M. L. C., Hesed nos Escritos de Oseias, p. 243.

${ }^{22}$ STUART, D., Hosea-Jonah, p. 188; SIMIAN-YOFRE, H., El Deserto de los Dioses, p. 163164; LIMA, M. L. C., Hesed nos Escritos de Oseias, p. 222-223; SILVA, C. H., The Literary Structure of Hosea 9-14, p. 443-446; RÖMER, T., Oseias, p. 465-467. Diop explana que o rîh usado explicitamente em Os 2,4;4,1;8,1;10,4 e 12,3 implica numa demanda legal da aliança (DIOP, G., The Name "Israel" and Related Expressions in the Books of Amos and Hosea, p. 242). Stuart observa que, no texto, "existem elementos que não são usualmente associados ao modelo de processo judicial": digressões históricas até a vida de Jacó (vv.4-5.13), e o fato de que o profeta fala no lugar de YHWH (exceto nos vv.1.10-11, onde Oseias parece estar citando as palavras de YHWH na primeira pessoa como uma base para a sua mensagem) (STUART, D., Hosea-Jonah, p. 188). Fretheim também chama a atenção para esta alternância entre a fala de YHWH e a fala de Oseias no cap. 12, mas explana que esta é "uma característica padrão do livro inteiro." (FRETHEIM, T. E., Reading Hosea-Micah, p. 68). Esta alternância entre o discurso de YHWH e o discurso de Oseias faz parte da alegoria do livro, onde o profeta encarna o sentimento de Deus, para tornar ainda mais real a profecia, e mostrar como o pecado do povo "tinha um impacto sobre a própria vida de Deus! Deus é confrontado diariamente com esta realidade, e, dada a natureza do relacionamento, não pode decidir simplesmente escapar dele!" (FRETHEIM, T. E., Reading Hosea-Micah, p. 68). Pentiuc chama a atenção para esta e outras passagens do Livro de Oseias, onde Deus aparece na primeira e na terceira pessoas $(4,10-15 ; 8,11-14 ; 12,1-$ 15) (PENTIUC, E. J., Long-Suffering Love, p. 14), e comenta: "Esta situação não usual reflete um relacionamento íntimo entre Yahweh e seu profeta." (PENTIUC, E. J., Long-Suffering Love, p. 14). Em Os 12, a fala de YHWH aparece nos vv.1.2.10.11. Já a fala de Oseias acontece nos vv. 3-9.12-15. Jiménez faz uma distinção entre o que ele chama de discurso divino e fala do profeta em todo o Livro de Oseias (JIMÉNEZ, C. S., El Desierto en el Profeta Oseas, p. 13). E diz: "O que há por trás desta linguagem é uma relação dialógica YHWH-profeta, que caracteriza toda a pregação de Oseias, sua maneira de comunicar-se como profeta. Este tipo de discurso divino devia ser muito evidente e facilmente identificável para os que o escutavam. Não é demasiado lembrar continuamente que o profeta pretendia apresentar a mesma voz de YHWH" 
aparece em 12,3a. O profeta é inspirado a usar elementos das práticas de controvérsia jurídica, com a acusação ou demanda judicial da parte contrária (vv.1-3, 9, 12) e o anúncio das sanções legais ou da execução da sentença (v.15). A presente perícope (Os 12,12-15) é um rî̉ menor dentro do rîb maior, que vem a ser o próprio cap. 12: v. 12 - acusação de YHWH contra seu povo / v. 15 - anúncio da sanção de YHWH sobre Seu povo. O Sitz im Leben deste texto (Os 12,12-15) é a contenda que Deus tem com seu povo de Israel, por causa da sua rebelião, idolatria, violência e falsidade. Esta demanda é o tema principal do discurso do profeta.

O modelo rîb (processo judicial) geralmente provê uma alternância entre acusação, evidência e sentença judicial. O v.12 (11) parece ser uma acusação, apresentando evidência para o tribunal divino, dando dois relatos de crimes contra a aliança. A menção mais geral da maldade de Galaad [...] Guilgal também se juntou à reputação de iniquidade [...] $\mathrm{O}$ processo legal é concluído (12:15 (14)) com uma sentença judicial redigida como uma predição de como Yahweh responderá ao ser tão irritado pela nação da aliança. ${ }^{23}$

\section{Crítica da Redação}

4.1. Correspondências vocabulares e semânticas de termos da perícope de Os 12,12-15 com o restante do livro

O vocabulário de Os 12,12-15 ocorre em grande parte do livro, e não raramente, com afinidade temática, como se pode conferir. No v.12a, o nome

(JIMÉNEZ, C. S., El Desierto en el Profeta Oseas, p. 14). Quanto ao rîb $\underline{b}$, Silva faz uma delimitação diferente da perícope, pois ele vê um oráculo de juízo nos vv.10-12 e outro nos vv.1315 (SILVA, C. H., The Literary Structure of Hosea 9-14, p. 443-446); o que se pode discordar, porque o v.10 não é uma denúncia ou acusação e o v.12 inicia uma nova perícope, como já foi demonstrado. Lima explica que este $r \hat{i} \underline{b}$ em Os 12 garante a unidade do texto, fazendo "com que todo o discurso seja apresentado como uma contenda, disputa de Yahweh, através do profeta, com o seu povo. [...] Temos assim no v.3 a colocação do ato - rîb - de disputa entre Yahweh e o povo, ato cuja consequência aparecerá claramente formulada no v.15, que fecha então o ato aberto no início do texto. Cabe observar a predominância da forma de acusação neste trecho, que é reforçada pela referência de que Deus é quem fala e age. A apresentação da culpa é feita de modo bastante amplo, o que conduz a ameaças genéricas e sucintas. Neste ponto, a fórmula breve de ameaça de punição nos v.3.15b - yā̌š $\underline{b} \underline{b}-l \hat{o}$ - forma como que uma moldura mais interna [...] que encontrando-se no v.3, primeira entrada retórica do capítulo, e no v.15, palavra de conclusão, enquadra todo o texto numa unidade" (LIMA, M. L. C., Hesed nos Escritos de Oseias, p. 223).

${ }^{23}$ STUART, D., Hosea-Jonah, p. 194-195. 
próprio "Galaad" é mencionado em Os 6,8 com o mesmo sentido que o tem aqui, negativo. O substantivo "וָוֹ ,iniquidade" (12a), ocorre outras seis vezes no livro de Oseias $(4,15 ; 5,8 ; 6,8 ; 10,5.8 ; 12,9)$; porém o horizonte semântico não é sempre o mesmo. Em 4,15; 5,8; 10,5 aparece na expressão bêt-'aven (casa vazia ou casa de nada) - como o epíteto depreciativo para se referir a Betel (em

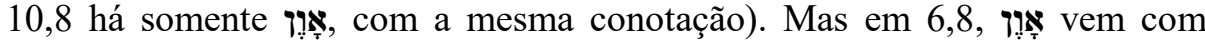
sentido semelhante ao que tem aqui em 12,12a (iniquidade, perversidade) e ligada à mesma cidade (Galaad). Já em 12,9 ocorre a mesma palavra com vocalização diferente (אi), cujo significado é "riqueza", "fortuna". "Guilgal" (v.12c): é mencionada em 4,15 e 9,15, com o mesmo sentido negativo que possui aqui. O vocábulo הִִִ̣ "seus altares" (v.12d), acontece outras três vezes em Oseias $(4,19 ; 10,2 ; 10,8)$, sempre associada à mesma ideia negativa:

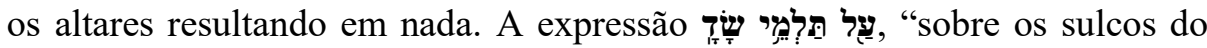
campo" (v.12d), aparece desta mesma forma em 10,4.

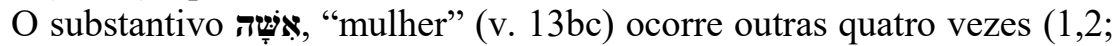
2,2; 3,1-2) com o mesmo sentido de esposa; sendo que a situação destas outras quatro citações é diferente da que aparece em 12,13; pois ao contrário desta, o contexto daquelas é o de uma mulher infiel.

O substantivo נִּבְיא, profeta (duas vezes no v.14), é visto em outras seis ocasiões no livro, com algumas ocorrências no plural $(4,5 ; 6,5 ; 9,7-8 ; 12,11)$. Em 4,5 e 6,5 a menção é aos falsos profetas. Os 9,7-8 indica que o texto se refere ao próprio profeta Oseias. Já 12,11 trata duas vezes dos profetas verdadeiros em geral, aqueles através dos quais Deus se comunica. "Egito" (14a): é citado outras dez vezes $(2,17 ; 7,11.16 ; 8,13 ; 9,3.6 ; 11,1.5 .11 ; 13,4)$, sempre numa perspectiva negativa; ora como lugar da escravidão $(2,17 ; 8,13$; $9,3 ; 11,1 ; 13,4)$; ora como ambiente de falsa segurança $(7,11.16 ; 9,6 ; 11,5.11)$.

"Efraim" (15a) é o nome próprio que mais se repete em Oseias, recorrendo outras 32 vezes $(4,17 ; 5,3(2 \mathrm{x}) .9 .11 .12 .13(2 \mathrm{x}) .14 ; 6,4.10 ; 7,1.8$ (2x).11; 8,11; 9,3.8.11.13.16; 10,6.11 (2x); 11,8.9; 12,1.2.9; 13,1.12.15; 14,9). Sempre usado como metonímia do Reino do Norte. Geralmente é empregado num contexto negativo de desobediência e imprecação; excetuando-se Os 13,1 (memória de um passado bom) e 14,9 (promessa de restauração futura). O substantivo $\boldsymbol{\Xi T ⿱ 龴 ⿵ ⺆}$, sangue (v.15b), encontra-se outras duas vezes no livro (1,4; $6,8)$, sempre num contexto de violência. Inclusive em 6,8 está associado a Galaad (nome que aparece no início da perícope que estamos analisando) também como metonímia para o Reino do Norte.

${ }^{24}$ ALONSO SCHÖKEL, L., אוֹן, p. 33; HOLLADAY, W. L. 81. 
4.2. Questões referentes à unidade redacional interna do capítulo 12 , e do mesmo com o restante do livro

As evidências textuais listadas acima indicam que o texto de 12,12-15 pertence ao mesmo nível básico da redação de Oseias. Entretanto, Wolff argumenta que a seção dos capítulos 12 a 14 de Oseias teria sido composta por habitantes de Judá:

Com respeito a isso, parece improvável que a presente configuração do terceiro complexo de Oseias (caps. 12-14) remonte ao próprio profeta, embora comece com o lamento de Oseias sobre sua rejeição no Reino do Norte (12:1). (...) Podem ser observadas algumas pequenas diferenças entre este terceiro complexo e os esboços dos caps. 4-11: a conjunção ’כ̣ que introduz as réplicas de Oseias a seus oponentes, é completamente ausente nos caps. 12-14; as unidades retóricas são repetidamente combinadas dentro de uma unidade querigmática unicamente pelo tema, não por conectivos estilísticos (cópula, pronome). Finalmente, a expressão "Eu sou Yahweh teu Deus" (12:10; 13:4; 14:2), que pertence a tradições litúrgicas, ocorre somente nestes capítulos. A doxologia inserida em 12:6 indica que esta transmissão complexa foi rapidamente proclamada de novo num cenário de adoração. Tudo isto aconteceu, de fato, em Judá, como vemos pela redação judaica de 12,3a, que difere de todos os outros comentários judaicos no livro. ${ }^{25}$

Sobre isto, fazem-se necessárias algumas observações: a) Como é que a unidade dos versículos que compõem a seção proposta de 12 a 14 não é corroborada por conectivos estilísticos, se nos tópicos das críticas literária e da forma deste artigo foram mostrados vários só no capítulo 12? b) Se os capítulos 12 a 14 foram inteiramente produzidos no Reino do Sul, como explicar os traços do hebraico israeliano que nele aparecem? c) Apesar de algumas das diferenças elencadas por Wolff serem inegáveis, e de não se poder descartar pela crítica histórica uma inserção judaica posterior em $12,1 \mathrm{~cd}$ ou $3 \mathrm{a}$; como justificar todas as identificações de vocabulário e tema que há desta seção com o restante da obra, conforme por exemplo, as muitas que estamos demonstrando aqui pela crítica da redação da perícope 12,12-15? d) Outro detalhe interessante de se reparar é que Os 12 contém a maior parte dos nomes próprios mencionados no restante do livro: Efraim (vv.1.2.15), Israel (vv.1.13.14), Judá (vv.1.3), Assíria

${ }^{25}$ WOLFF, H. W., Hosea, p. xxxi-xxxii. 
(v.2), Egito (v.2.10.14), Jacó (vv.3.13), Betel (v.5), Canaã (v.8), Galaad (v.12) e Guilgal (v.12).

Simian-Yofre não acredita que as menções a Judá sejam evidência de que tenha havido uma redação judaica no livro de Oseias, e escreve: "Em um texto onde a acusação contra Efraim chega às raízes, remontando-se ao antepassado Jacó, não é ilógico que o profeta queira incluir também a Judá, não só por ser descendente de Jacó, senão porque, ao menos parcialmente, é corresponsável das culpas de Efraim". ${ }^{26}$

Sweeney levanta a seguinte hipótese: "parece que Oseias teve de deixar o Israel do Norte em algum momento e se estabeleceu em Judá. [...] De fato, o livro de Oseias parece ter sido completado em Judá, e aponta para a restauração do governo judeu davídico sobre o reino do norte de Israel (Os 3:1-5)!" ${ }^{27}$ Aqui Sweeney parece estar ecoando uma sugestão do período patrístico, mais precisamente feita por Juliano, bispo de Eclano, do séc. V, segundo o qual o Profeta Oseias teria continuado seu ministério em Judá, após a queda de Samaria (722 a.C.). ${ }^{28}$ Todavia, conquanto esta hipótese não possa ser descartada, algumas ponderações são importantes: a) esta informação é tardia (datando de aproximadamente 1.100 anos depois do tempo do profeta); b) nada consta sobre esta imigração de Oseias em seu próprio livro; e c) Juliano de Eclano não especifica que Oseias teria escrito os caps. 12 a 14 em Judá.

Gruber defende a divisão do livro, não em três seções como o fez Wolff (1-3; 4-11; 12-14), mas em duas: $1-3$ e 4-14, com os caps. 12-14 fazendo parte do mesmo nível de redação básica de $4-11{ }^{29}$ Ele admite que houve redações judaicas posteriores e indica em quais versículos provavelmente elas teriam acontecido: Os 1,$7 ; 5,12-14 ; 6,4 ; 10: 11 ; 12,1.3$. Ele sugere que nestes textos o nome "Israel" foi intencionalmente mudado por copistas sulistas para "Judá" (no hebraico começam com a mesma consoante '), objetivando tornar a

\footnotetext{
${ }^{26}$ SIMIAN-YOFRE, H., El Deserto de los Dioses, p. 160-161.

${ }^{27}$ SWEENEY, M. A., The Twelve Prophets, p. 5-6.

${ }^{28}$ PENTIUC, E. J., Long-Suffering Love, p. 10.

${ }^{29}$ GRUBER, M. I., Hosea, p. 7, 11-12; DIOP, G., The Name "Israel” and Related Expressions in the Book of Amos and Hosea, p. 234; WYRTZEN, D. B., The Theological Center of the Book of Hosea, p. 316. Dearman também divide o Livro de Oseias em duas grandes seções que são os capítulos 1-3 e 4-14; embora veja uma subdivisão de dois painéis entre os capítulos 4-11 e 12 14. A primeira seção (1-3) ele denomina "A Família de Oseias", e a segunda seção (4-14) ele chama "Deus e Seu Povo" (DEARMAN, J. A., The Book of Hosea, p. 11-19). Outro autor, Mackay endossa a divisão 1-3 e 4-14, sendo que, para ele, a divisão 4-14 é formada por três blocos, que no Texto Hebraico equivalem a: 4,1-6,3; 6,4-11,11; 12,1-14,10 (MACKAY, J. L., Oseias, p. 24-25).
} 
mensagem pertinente ao Reino do Sul. ${ }^{30}$ Lima, por sua análise de Os 12, também conclui "que uma redação judaica é de se supor pelas referências a Judá, bem como pela fórmula cúltica do v. 6". ${ }^{31}$

Alonso Schökel e Sicre Diaz consideram a possibilidade do v. 1cd "ser original do profeta, desejoso de que o reino do sul ouça e aprenda". ${ }^{32}$ Contudo, logo em seguida, na mesma frase em que fazem esta consideração, eles ponderam, por outro lado, que $1 \mathrm{~cd}$ pode se tratar de uma inserção posterior do redator para introduzir Judá. ${ }^{33} \mathrm{Na}$ mesma página também, os autores já dão por certo que o nome "Judá" no v. 3a é de autoria de um escriba judaíta, que quis aplicar a profecia a seu próprio povo, pois tudo o que se segue no texto trata de Israel. ${ }^{34}$

Para Dearman, as referências a Judá no Livro de Oseias são bastante obscuras. Ele cita a menção de Judá em Os 12,1 como sendo possivelmente editorial. ${ }^{35}$ Contudo, ele pondera que editorial pode significar muita coisa: a) o próprio Oseias pode ter atualizado o seu material em contextos de mudança; b) quando o material de Oseias foi levado para Judá, antes ou depois da campanha militar de Tiglate-Pileser III na região (733-732 a.C.), pode ter havido um trabalho editorial; c) outra possibilidade é a de que os materiais de Oseias tenham sido atualizados pelos círculos reformistas do tempo de Josias e Jeremias, devido à inegável influência da obra de Oseias sobre Jeremias; e d) finalmente, esta atualização para apresentação ao povo de Judá pode ter continuado no período do exílio babilônico. ${ }^{36}$ Entretanto, Dearman observa também que, o fato de algumas referências a Judá em Oseias serem positivas

${ }^{30}$ GRUBER, M. I., Hosea, p. 27-31, 494, 498.

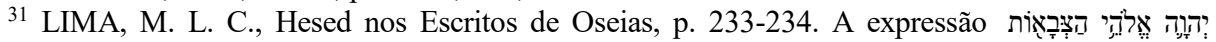
("YHWH, Deus dos Exércitos" (Os 12,6a) aparece também em Am 3,13; 4,13; 9,5. Vale lembrar que Amós era contemporâneo de Oseias e, embora tenha profetizado tanto para Judá quanto para Israel, tinha sua origem no Reino do Sul, ele era natural da cidade de Técua (Am 1,1). Todavia, Van Ruiten secciona Os 12, a partir do v.3, em três estrofes, nas quais podem ser vistas três acusações contra defeitos de caráter do povo (vv.3.4a.8.9.12), seguidas por três declarações das virtudes de Deus (vv.6.7.10.11.12) (VAN RUITEN, J., The Image of Jacob in the Targum of Hosea 12, p. 601). Assim, uma outra possibilidade seria o fato de a fórmula cúltica do v. 6 fazer parte deste contraste estilístico que teria sido composto pelo autor original, e que consequentemente faria parte da estrutura básica do cap. 12. Pouco adiante, Van Ruiten comenta: "Embora Os 12:6 seja reputado por muitos exegetas como uma adição posterior, a forma final do texto pode ser considerada uma continuação de Os 12:5cd, uma continuação que torna explícito quem Jacó encontrara em Betel" (VAN RUITEN, J., The Image of Jacob in the Targum of Hosea 12, p. 606).

32 ALONSO SCHÖKEL, L.; SICRE DIAZ, J. L., Profetas II, p. 943.

${ }^{33}$ ALONSO SCHÖKEL, L.; SICRE DIAZ, J. L., Profetas II, p. 943.

${ }^{34}$ ALONSO SCHÖKEL, L.; SICRE DIAZ, J. L., Profetas II, p. 943.

35 DEARMAN, J. A., The Book of Hosea, p. 19.

${ }^{36}$ DEARMAN, J. A., The Book of Hosea, p. 19-20. 
$(1,7 ; 2,2 ; 12,1)$, não é motivo para caracterizá-las necessariamente como editoriais, embora isso seja definido por alguns intérpretes. Segundo ele, a caracterização das referências positivas a Judá como sendo acréscimos ao material de Oseias, deveria ser feita com base em critérios literários e semânticos, em vez de ser por questões geográficas ou políticas. ${ }^{37}$

Andersen e Freedman consideram as referências a Judá como sendo autênticas do autor original de Oseias. ${ }^{38}$ Para eles, a menção a Judá em Os 12,1cd não é positiva, mas negativa, tal qual no v.3. ${ }^{39}$ Daí, traduzem o v.1cd da seguinte maneira: "Judá ainda caminha com os deuses santos, ele é fiel aos deuses santos". ${ }^{40}$ Mas esta tradução não é literal, e a passagem é de difícil tradução, não

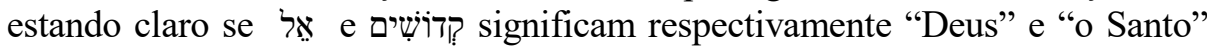
(plural de majestade), ou "um deus" e "uns santos". Andersen e Freedman, eles recordam o leitor de vários "outros lugares em Oseias onde Judá e Efraim(Israel) são tratados dessa mesma perspectiva negativa (Os 5:5, 10-13; 6:4, 10-11; 8:14; 10:11)" ${ }^{41}$ Para eles, pôr de lado toda esta evidência "ao ler-se 'Israel' em vez de Judá no v.3a, "é um passo desesperado, embora popular". 42

Hubbard segue uma linha de raciocínio muito semelhante à de Andersen e Freedman. Segundo ele, "a questão das referências a Judá é complexa, e cada ocorrência merece sua própria análise". ${ }^{43}$ Ele não está convencido de que haja algum motivo a priori para se eliminar Judá do campo visual de Oseias. O profeta devia estar familiarizado com o papel histórico de Judá no plano de Javé. Seu compromisso com a aliança, que ele considerava pertinente a todo o povo de Deus, deve ter levado Oseias a aplicar seus julgamentos e bênçãos a Judá, bem como às suas próprias tribos do norte. ${ }^{44}$

Sobre a menção de Judá em Os 12,1cd, Hubbard explana:

Oseias amplia seus horizontes para incluir Judá, o reino do sul. Os erros fundamentais que o profeta é compelido a apontar - idolatria, loucura política, autoconfiança militar - não eram propriedade particular de um dos

\footnotetext{
${ }^{37}$ DEARMAN, J. A., The Book of Hosea, p. 20.

${ }^{38}$ ANDERSEN, F. I.; FREEDMAN, D. N., Hosea, p. 601.

${ }^{39}$ ANDERSEN, F. I.; FREEDMAN, D. N., Hosea, p. 601.

${ }^{40}$ ANDERSEN, F. I.; FREEDMAN, D. N., Hosea, p. 597.

${ }^{41}$ ANDERSEN, F. I.; FREEDMAN, D. N., Hosea, p. 601.

${ }^{42}$ ANDERSEN, F. I.; FREEDMAN, D. N., Hosea, p. 601.

${ }^{43}$ HUBBARD, D. A., Oseias, p. 37-38.

${ }^{44}$ HUBBARD, D. A., Oseias, p. 38. Pentiuc vai numa linha de raciocínio muito semelhante à de Hubbard, e diz que Oseias, embora fosse proveniente do Reino do Norte, "comportava-se como um verdadeiro profeta que, tendo sido chamado e enviado por Yahweh, comunicou sua palavra a todo o povo, a despeito das fronteiras geopolíticas.” (PENTIUC, E. J., Long-Suffering Love, p. 20).
} 
dois reinos. Na qualidade de mensageiro divinamente comissionado e intérprete da aliança, Oseias não podia limitar suas palavras às fronteiras artificiais que separavam sua terra e a de seu irmão do sul. [...] as menções a Judá são lembretes de que o pecado não precisa de passaporte; ele atravessa as fronteiras sem passar pela alfândega e brota endemicamente em qualquer solo que esteja à disposição. Além disso, os planos divinos de longo prazo requeriam um povo congregado (1.11 (texto hebraico: 2,2)), e as punhaladas de Oseias contra Judá, nos discursos de juízo, mantiveram essa realidade perante seus ouvintes do norte. ${ }^{45}$

Sendo assim, este exegeta também interpreta a referência a Judá no v. $1 \mathrm{~cd}$ como sendo negativa, tais quais Andersen e Freedman. Hubbard entende que o vocábulo אה "aqui provavelmente significa El, o deus supremo dos cananeus, não Javé". ${ }^{46}$ Ele argumenta que קִ não seria um plural majestático para YHWH, mas uma designação do "panteão cananeu, que abrange a corte de El" ${ }^{47}$ Desta maneira, sua tradução ficou assim: "Judá ainda vagueia com El e se mantém fiel aos 'santos' (da corte de El)". ${ }^{48}$

Hubbard considera que muitos estudiosos têm a compreensão de que um editor judeu posterior substituiu o nome "Israel" por "Judá" no v. 3a. ${ }^{49}$ Mas ele também apresenta a possibilidade de que o nome de Judá seja um lembrete de que todo o povo herdou, tanto as características ímpias ou tolas de seu ancestral comum, quanto as promessas da aliança que farão deles um só povo mais uma vez. ${ }^{50}$ Ainda segundo o comentarista, Jacó (vv.3.12) e Israel (vv.13-14) referem-se ao pai das duas tribos, do norte e do sul, e de todas as tribos resgatadas do Egito no êxodo; neste capítulo (vv.9.15), Efraim significa reino do norte, sendo também a contraparte estilística de Judá. ${ }^{51}$

De acordo com Mackay, a menção a Judá no v. 1cd também seria de um ponto de vista negativo. Ele traduz a passagem da seguinte maneira: "e Judá está continuamente vagueando com El, e sendo fiel àqueles aos quais (ele considera) santos". ${ }^{52}$ Contudo, a expressão "ele considera" é forçada, funcionando mais como uma interpretação do que como uma tradução. Entretanto, o escritor dá uma justificativa interessante do porquê Judá poderia estar sob um prisma negativo.

\footnotetext{
${ }^{45}$ HUBBARD, D. A., Oseias, p. 211-212.

${ }^{46}$ HUBBARD, D. A., Oseias, p. 212.

${ }^{47}$ HUBBARD, D. A., Oseias, p. 212.

${ }^{48}$ HUBBARD, D. A., Oseias, p. 212.

${ }^{49}$ HUBBARD, D. A., Oseias, p. 215.

${ }^{50}$ HUBBARD, D. A., Oseias, p. 215.

${ }^{51}$ HUBBARD, D. A., Oseias, p. 215.

${ }^{52}$ MACKAY, J. L., Oseias, p. 331-333.
} 
Mackay lembra que um dos reis sulistas contemporâneos de Oseias foi Acaz (Os $1,1)$; e que na descrição dos atos deste rei em 2Rs 16,3-4.10-15, eles são comparados, em impiedade, aos dos reis de Israel. ${ }^{53}$

Outro especialista, Fretheim, não descarta a possibilidade de que as referências a Judá em Oseias sejam uma inserção para aplicar a mensagem do livro ao Reino do Sul, mas lembra que todos os manuscritos deste livro, disponíveis até agora, incluem ambos: Israel e Judá. ${ }^{54}$ Ele analisa que a denúncia contra Judá no v. 3a é uma evidência de que a tradução do v. 1cd também deveria ser num sentido negativo. ${ }^{55} \mathrm{E}$ propõe a seguinte leitura: "Judá é indisciplinado contra Deus, que permanece fiel aos seus santos" ${ }^{56}$ Quanto à sua tradução do verbo no particípio, נִֵֶ, com valor relativo, está certa. A dificuldade está na tradução de uma mesma preposição (צ̣), numa mesma frase, primeiro com sentido negativo ("contra"), e logo depois com sentido positivo ("a" / "para com"). Outro problema é a o pronome demonstrativo de $3^{\mathrm{a}}$ pessoa do plural (seus), cujo correspondente não há no TM.

Stuart declara que não há evidência textual para apoiar a retirada apenas do nome de Judá do v. $1 \mathrm{~cd} .{ }^{57}$ Mas, ao mesmo tempo, ele afirma que este trecho provavelmente não foi do autor original do Livro de Oseias. ${ }^{58}$ Todavia, Stuart considera que o nome "Judá" pertenceria ao texto original do v. $3 \mathrm{a}$, não se tratando de uma substituição posterior para Israel. ${ }^{59}$ E complementa: "nós estamos lidando aqui com uma passagem muito mais preocupada com todo o Israel". ${ }^{60}$ É curioso notar que, mesmo Stuart crendo que o v. 1cd seja uma glosa posterior, traduz as duas orações aqui de forma negativa.$^{61}$ Contudo, a tradução dele ficou assim: "E Judá permanece indisciplinado contra Deus, até mesmo contra o Santo fiel". ${ }^{62}$ Ele interpretou a preposição yִ com o significado de "contra" nas duas orações, קִ pִ como sendo um plural de majestade, e

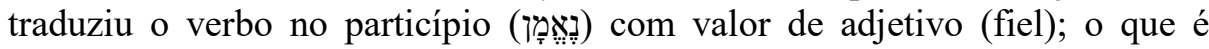
perfeitamente possível.

\footnotetext{
${ }^{53}$ MACKAY, J. L., Oseias, p. 331-333.

${ }^{54}$ FRETHEIM, T. E., Reading Hosea-Micah, p. 68; MACKAY, J. L., Oseias, p. 335.

${ }^{55}$ FRETHEIM, T. E., Reading Hosea-Micah, p. 68.

${ }^{56}$ FRETHEIM, T. E., Reading Hosea-Micah, p. 68.

${ }^{57}$ STUART, D., Hosea-Jonah, p. 186.

${ }^{58}$ STUART, D., Hosea-Jonah, p. 186.

${ }^{59}$ STUART, D., Hosea-Jonah, p. 186.

${ }^{60}$ STUART, D., Hosea-Jonah, p. 186.

${ }^{61}$ STUART, D., Hosea-Jonah, p. 185.

${ }^{62}$ STUART, D., Hosea-Jonah, p. 185.
} 
O duvidoso é o sentido do verbo רוד, aqui (qal qatal $3^{\text {a }}$ pes. mas. sg.), que no qal pode significar "vagar", "perambular", "caminhar", "andar", "ir-se", "vaguear impacientemente". ${ }^{63}$ Em Os 12,1, o significado deste vocábulo é controverso. ${ }^{64}$ Por exemplo, a Nova Versão Internacional traduz este mesmo texto (que lá se encontra em Os 11,12cd) da seguinte maneira: "e Judá é rebelde contra Deus, a saber, contra o Santo fiel". ${ }^{65}$ Como se pode perceber, uma tradução bem parecida com a de Stuart. Uma outra tradução, que siga esta mesma interpretação negativa sobre Judá, seria: "e Judá ainda vai contra Deus, contra o Santo fiel". O entendimento de que קִ possa ser traduzido como um plural de majestade para o Deus de Israel, encontra correspondente na Bíblia Hebraica (Pv 9,10; 30,3); algo semelhante ao que acontece com o termo אלֶהים.

Por esta crítica da redação do capítulo 12 de Oseias, pode-se chegar às seguintes conclusões: a) não há fundamento para se dizer que a suposta seção dos capítulos 12-14 do livro teria sido inteiramente composta posteriormente em Judá, seja pelo próprio profeta, seja por um escriba ou ainda um grupo de escribas; b) não há dúvidas de que a perícope de Os 12,12-15 pertença ao nível básico pelo menos da redação da seção 4-14, possuindo inclusive algumas correspondências vocabulares, semânticas e temáticas com os caps. 1-3, conforme encontram-se listadas no subtópico anterior deste artigo (4.1); e c) pelo método científico não é possível determinar, até o presente momento, se os vv.1cd.3a.6 foram interpolações redacionais judaicas posteriores ou não.

\section{Crítica das Tradições}

Duas tradições aparecem explícitas na perícope que estamos estudando: uma dos patriarcas, mais especificamente de Jacó (v.13); ${ }^{66}$ e outra do êxodo (v.14) ${ }^{67}$ No v.14b estão implícitos também o tema tradicional do deserto e uma tradição de Moisés. ${ }^{68}$ Andersen e Freedman afirmam que, provavelmente, as linhas dos

\footnotetext{
${ }^{63}$ DAVIDSON, B., רוד, p. 677; ALONSO SCHÖKEL, L., רוד, p. 608; WHITE, W., רוד, p. 1405. ${ }^{64}$ ALONSO SCHÖKEL, L., רוד, p. 608; HOLLADAY, W. L., רוד, p. 475; MARTENS, E. A., רוד, p. 1063-1064.

${ }^{65}$ Discordando desta análise, Lim advoga que uma leitura pró-judaica deve ser mantida no v.1, e entende que, no v.3, o nome Efraim, ou Israel, ou Jacó, teria sido substituído pelo nome "Judá" (LIM, B. H., Hosea 11:12-13:16 (12:1-14:1], p. 201).

${ }^{66}$ Nas imagens da mulher e do pastoreio, podem ser vistas as características genealógica e tribal da tradição de Jacó, que também estão contidas neste v.13 (JIMÉNEZ, C. S., El Desierto en el Profeta Oseas, p. 178).

${ }^{67}$ JIMÉNEZ, C. S., El Desierto en el Profeta Oseas, p. 180-181.

68 JIMÉNEZ, C. S., El Desierto en el Profeta Oseas, p. 179-180.
} 
vv.13.14 já chegaram prontas para Oseias, e que ele simplesmente as está citando. ${ }^{69}$ Wolff acredita na influência de uma tradição deuteronomista em todo o livro de Oseias, argumentando primeiramente que o profeta foi contemporâneo dos precursores do movimento deuteronômico. ${ }^{70}$ Em seguida, ele declara:

Complexos inteiros do pensamento característico da exortação deuteronômica ocorrem pela primeira vez em Oseias. Assim encontramos reminiscências do êxodo do Egito, da guia divina através do deserto e da entrada na terra fértil; combinadas com os temas da saciedade e da presunção de Israel, bem como o do seu esquecimento de Yahweh. ${ }^{71}$

Ele prossegue elencando outros temas que são comuns a Oseias e a Deuteronômio: "A luta contra as alianças políticas de Israel, a maneira que se fala da torah, Yahweh como o 'Professor' de Israel, o amor de Yahweh, a redenção, o profeta genuíno que está 'com Deus', a fraternidade, [...], grão, vinho novo e azeite de oliva".72

Comentando sobre Os 12,14, Wolff conclui: "Não pode ser negado que aqui 'profeta' significa Moisés, a partir do momento em que uma conexão é feita com o êxodo do Egito. Isto recebe apoio indireto pelo fato de que os círculos deuteronômicos, cujos começos podem ser traçados até Oseias, chamam Moisés de 'um profeta' (Dt 18,15ss)". ${ }^{73}$

Não podem ser negadas as similaridades que existem entre o ciclo do Patriarca Jacó, conforme o Livro de Gênesis $(25,19-37,1 \mathrm{ab})$, e aquele que é relatado em Oseias (12,4-5.13):

\begin{tabular}{|c|c|c|}
\hline $\begin{array}{c}\text { Jacó nasce agarrado ao } \\
\text { calcanhar de seu irmão }\end{array}$ & Os 12,4a & Gn 25,26 \\
\hline Jacó luta com Deus & Os 12,4b-5c & Gn 32,23-33 \\
\hline $\begin{array}{c}\text { Deus encontra Jacó e fala com } \\
\text { ele em Betel }\end{array}$ & Os 12,5de & Gn 28,10-22; 35,1-8 \\
\hline Jacó foge para Aram & Os 12,13a & Gn 27,43;28,2.5 \\
\hline
\end{tabular}

\footnotetext{
${ }^{69}$ ANDERSEN, F. I.; FREEDMAN, D. N., Hosea, p. 621.

${ }^{70}$ WOLFF, H. W., Hosea, p. xxxi.

${ }^{71}$ WOLFF, H. W., Hosea, p. xxxi.

${ }^{72}$ WOLFF, H. W., Hosea, p. xxxi.

${ }^{73}$ WOLFF, H. W., Hosea, p. 216.
} 
Jacó trabalha para o seu tio Labão por amor a Raquel
Os $13 b c$

Gn $29,15-30^{74}$

Em Os 12,4a ocorre o mesmo jogo de palavras pela relação entre a

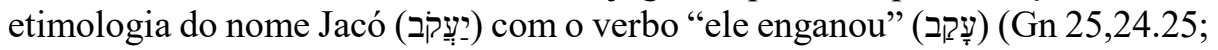
27,36). Há semelhanças entre outros verbos empregados também: a) a cadeia "ele lutou... ele prevaleceu" (יכל ... שָרָרה) (Gn 32,29; Os 12,4b.5b); b) "ele fugiu"

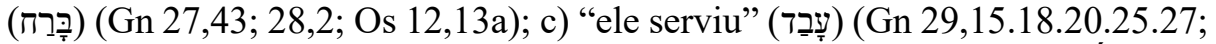
31,41; Os 12,13b); $;^{75}$ e d) "ele guardou” (שָׁמַר) (Gn 30,31; Os 12,13c). É digno de nota que, em nenhum ponto, o relato de Oseias sobre Jacó contradiz o de Gênesis. Até mesmo a mudança do seu nome para Israel é aludida (Os 12,13).

Sobre a tradição do êxodo, Oseias tem muitas referências às tradições conectadas com Moisés no contexto bíblico: a) a libertação da escravidão no Egito (Os 2,17; 11,1; 12,14; 13,4 // Ex 13-15); b) a aliança do Sinai, onde YHWH constitui Israel como seu povo e a si mesmo como o seu Deus (Os 2,25 // Ex 19,5-6); c) alguns mandamentos do Decálogo (Os 4,2 // Ex 20,13-16 // Dt 5,17-20); e d) a peregrinação no deserto (Os 9,10a). ${ }^{76}$ Além disso,

Oseias parece conhecer algo dos materiais legais da Torah. Por exemplo, em Oseias 4,2 o profeta parece estar aludindo ao Decálogo (Ex 20,1-17; Dt 5,6-21). Em Os 4,17; 8,4; 11,2 e 13,2 ele ecoa a proibição da idolatria em Lv 19,4; 26,1.30 (cf. Dt 29,17; 32,21). Em Os 5,3 e 6,10 ele sabe que o adultério causa mácula ( $\operatorname{Lv} 18,20)$. Semelhantemente, em Os 9,4 ele está ciente de que um cadáver polui tudo ao seu redor (Nm 19,14-16). ${ }^{77}$

Ramirez chama a atenção para outro dado muito importante: A pesquisa do Pentateuco tem estabelecido a origem separada das tradições patriarcais das tradições mosaicas. Há bastante tempo, a maioria dos críticos do AT assegura que as narrativas patriarcais (Gn 12-36), juntamente com a história dos começos (Gn 1-11) e a história de José (Gn 37-48), foram combinadas com as histórias do êxodo, da jornada no deserto e da aliança no Sinai muito tempo depois, no século V a.C. Não podemos precisar quando as duas tradições se tornaram

\footnotetext{
${ }^{74}$ Simian-Yofre demonstra admiração pela íntima relação que existe entre a história de Jacó no Livro de Gênesis e os relatos sobre o mesmo patriarca no capítulo 12 de Oseias (SIMIANYOFRE, H., El Deserto de los Dioses, p. 155-159).

${ }^{75}$ Inclusive a expressão צִָּ (ele serviu por), de Os 12,13b, consta em Gn 29,18; 31,41.

${ }^{76}$ RAMIREZ, F. F. L., Are the Allusions to Jacob and Moses in Hosea 12 Late Insertions?, p. 120-121; MACKAY, J. L., Oseias, p. 32, 336.

${ }^{77}$ RAMIREZ, F. F. L., Are the Allusions to Jacob and Moses in Hosea 12 Late Insertions?, p. 121.
} 
coexistentes, mas o fato é que em Oseias 12 uma parte das tradições patriarcais e outra das tradições do êxodo se encontram lado a lado, e isto na segunda metade do séc. VIII a.C.; e o autor sagrado escreve sobre elas, não como quem conta um relato, mas como quem comenta para quem já conhece. ${ }^{78}$

\section{Comentário Exegético}

Um comentário pode ser feito versículo por versículo, parte por parte ou ainda por temas. Na presente pesquisa, escolheu-se este terceiro modelo. É pertinente notar que a perícope de Os 12,12-15 menciona determinados nomes, que são: Galaad, Guilgal, Jacó, YHWH, Israel, Egito e Efraim; sendo os cinco últimos supracitados no capítulo 12, e todos eles citados algumas vezes ao longo do livro. Isto porque, nas Escrituras, um nome dá identidade a um indivíduo e/ou a um povo, sendo usado também para descrever o seu caráter ${ }^{79}$ e esperançar o seu futuro.

\subsection{Galaad (v.12a)}

"Galaad" (Os 12, 12a) é uma região montanhosa ${ }^{80}$ situada a leste do Rio Jordão, onde Labão encontrou seu sobrinho Jacó, que fugia dele (Gn 31,21-25). Ali eles fizeram uma aliança e erigiram um "montão de pedras" ( $g a l)$ em testemunho. Foi a partir desse momento, que o lugar passou a se chamar "Galaad". (Gn 31,44-54). Galaad, na etimologia, tem a ver com os "montões de pedras" (galîm) de Guilgal (Os 12,12cd), e, na história, com Jacó $(12,13){ }^{81}$

Em Os 10,2-3 há uma conexão entre a derrubada dos altares e estelas com a derrubada do rei. "Visto que Galaad é uma iniquidade, apenas um vazio eles são" (Os 12,12ab). O mesmo local é citado em Os 6,8, como "uma cidade de iniquidade, pisada de sangue", cujos próprios sacerdotes são acusados de

\footnotetext{
${ }^{78}$ RAMIREZ, F. F. L., Are the Allusions to Jacob and Moses in Hosea 12 Late Insertions?, p. 121, 137; MACKAY, J. L., Oseias, p. 33. Simian-Yofre chega a declarar que a audiência de Oseias conhece a história do Gênesis, e que reconhece Jacó aqui (SIMIAN-YOFRE, H., El Deserto de los Dioses, p. 159).

${ }^{79}$ LIM, B. H., Hosea 11:12-13:16 (12:1-14:1), p. 203.

${ }^{80}$ Em Os 6,8 Galaad é mencionada como uma cidade. Champlin observa o seguinte: Como, na literatura bíblica ou extra-bíblica não há qualquer outra indicação de Galaad como uma cidade, e sim como uma região, a interpretação correta do texto de Os 6,8 deveria ser: "Galaad é como uma cidade..." (CHAMPLIN, R. N., Gileade, p. 907).

${ }^{81}$ SIMIAN-YOFRE, H., El Deserto de los Dioses, p. 158; KALLAND, E. S., דִִִּ p. 272-273; CHAMPLIN, R. N., Gileade, p. 906-907; LIM, B. H., Hosea 11:12-13:16 (12:1-14:1), p. 209; MACKAY, J. L., Oseias, p. 352.
} 
crimes de assassinato. Semelhantemente a 12,12 , em 6,8 a associação é feita diretamente da região com o pecado. No paralelismo de 12,12ab, a associação subsequente se dá entre seus habitantes pecadores com a nulidade. A teologia do Livro de Oseias ensina que, quem se associa ao pecado, torna-se completamente vazio $(12,2 ; 5,11)$.

Houve profecias, segundo as quais, depois que Israel voltasse do cativeiro, voltaria a possuir Galaad (Ab 19; Zc 10,10), o povo se alimentaria ali (Mq 7,14), e ali se fartaria (Jr 50,19). Após o fim do exílio babilônico,

Tobias foi nomeado governador do território de Amom, que ficava contíguo a província de Gileade, e começou a governar como subordinado do imperador persa. Em 163 a.C., Judas Macabeu recuperou, temporariamente, a região de Gileade (Galaade), e transportou muitos de seus moradores para Judá. (I Macabeus 5:9-54). Nos dias do Novo Testamento, Gileade passara a fazer parte da Peréia. ${ }^{82}$

\subsection{Guilgal (v.12b)}

"Guilgal" fora uma cidade reputada como iníqua também em Os 4,15; 9,15; e ainda em Am 5,5. Pelas Escrituras Hebraicas, parece ter havido pelo menos quatro lugares diferentes chamados Guilgal ${ }^{83}$ Mas, o local mencionado em Oseias é o mais falado no AT. A cidade em questão se situava a leste de Jericó, mais precisamente, entre esta e o Jordão ${ }^{84}$ Após a travessia deste rio, Josué erigiu em Guilgal uma coluna com doze pedras que retirara das águas (Js 4,19-20), e que lembra os "montões de pedras" aqui, de Os 12,12d. Ali, de acordo com o relato do Livro de Josué, aquela geração de hebreus foi circuncidada, Deus retirou deles a desonra que carregaram no Egito, celebraram a primeira Páscoa em Canaã e o maná cessou de cair (Js 5,9-12). Foi em Guilgal que Josué dividiu pelo menos uma parte da terra (Js 14,6). Do ponto de vista geográfico, Mackay argumenta que Galaad estava localizada na Transjordânia, enquanto Guilgal "ficava perto da fronteira sul do reino do norte. O que era verdadeiro a respeito delas seria igualmente verdadeiro a respeito da nação

${ }^{82}$ CHAMPLIN, R. N., Gileade, p. 907.

${ }^{83}$ Em relação aos três menos conhecidos: "Deuteronômio 11.30 situa Ebal e Gerizim 'defronte de Gilgal', que parece estar próximo de Siquém. O Gilgal de Elias e Eliseu fica perto de Betel (2Rs $2.1 ; 4.38$ ). Ali Eliseu purifica para os filhos dos profetas a comida indicada pela expressão 'morte na panela'. [...] Gilgal é também uma cidade limítrofe de Judá mencionada em Josué 15.17

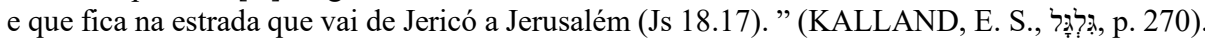

${ }^{84}$ CHAMPLIN, R. N., Gilgal, p. 907. 
como um todo" ${ }^{85}$ Atualmente, esta antiga cidade bíblica é identificada com o sítio arqueológico de Khirbet el-Mefjir. ${ }^{86}$

Guilgal estava associada ao início da monarquia em Israel, com a história de Saul, pois foi ali que ele foi proclamado rei por Samuel e aclamado pelo povo (1Sm 11,14-15). Ali também por duas vezes Saul desobedeceu a Deus: a) oferecendo sacrifícios, sem ser um sacerdote (1Sm 13,4.7-15); e b) guardando parte do rebanho de Amaleque para oferecer em sacrifício (1Sm 15,12.21-33).

"Em Guilgal sacrificam touros, também seus altares serão como montões de pedras sobre os sulcos do campo" (Os 12,12cd). Guilgal é citada como uma cidade de muitos altares, e por isso era um local de peregrinação religiosa também (Os 4,15; Am 4,4; 5,5). ${ }^{87} \mathrm{O}$ fato de as três palavras (gil'ād-gilgāl galîm (montões de pedras)) começarem com as mesmas duas consoantes $(g l)$, provocava um jogo de palavras e o fenômeno da aliteração, talvez como um recurso para tornar a profecia memorável para a audiência. ${ }^{88}$ Amós também profetizou a destruição de Guilgal, só que ele detalhou que ela ocorreria por meio do exílio (Am 5,5).

Samuel advertira a Saul em Guilgal: "Que prazer tem YHWH em holocaustos e sacrifícios, quanto em que se obedeça a voz de YHWH? Eis que o obedecer é melhor do que um sacrifício, e prestar atenção é melhor do que a gordura de carneiros. Porque a rebelião é o pecado de adivinhação; e ser obstinado é iniquidade e ídolos..." (1 Sm 15,22-23b). Oseias adverte reiteradamente que, quando uma pessoa presta um culto ao Senhor, mantendo atitudes de desobediência a ele, sua adoração é completamente vã, inútil e efêmera (Os 4,19; 8,13; 10,8).

\subsection{Efraim (v.15a)}

"Efraim" (Os 12,15a) é o nome do filho mais novo de José. A bênção superior que seu avô Jacó deu a Efraim em relação a seu irmão mais velho Manassés, é interpretada como um sinal de que ele teria a proeminência ( $\mathrm{Gn}$ 48,14.17-20). A força de Efraim se revela desde $\mathrm{Nm} \mathrm{1,33,} \mathrm{quando} \mathrm{o} \mathrm{número} \mathrm{de}$ seus homens para a guerra somava 40.500. "Desde a conquista de Canaã, a tribo era totalmente zelosa de seu prestígio. (Jz 7.24; 8,1; 12.1ss)". ${ }^{89}$ Samuel, que foi

\footnotetext{
${ }^{85}$ MACKAY, J. L., Oseias, p. 350.

${ }^{86}$ PENTIUC, E. J., Long-Suffering Love, p. 358.

${ }^{87}$ GRUBER, M. I., Hosea, p. 516.

${ }^{88}$ ANDERSEN, F. I.; FREEDMAN, D. N., Hosea, p. 620; STUART, D., Hosea-Jonah, p. $194-$ 195; MACKAY, J. L., Oseias, p. 351-352; GRUBER, M. I., Hosea, p. 516.

${ }^{89}$ FEINBERG, C. L., אֶפְרִיִ, p. 111.
} 
juiz, sacerdote e profeta, era da tribo de Efraim $(1 \mathrm{Sm} \mathrm{1,1)}$. Siló, cidade do santuário na época dos juízes, ficava ali (1Sm 1,3.9.24; 2,14; 3,21).

Quando a extravagância de Salomão e a incapacidade de Roboão trouxeram descontentamento geral contra a dinastia davídica, o efraimita Jeroboão tirou plena vantagem da situação. Desde a queda do reinado salomônico até a conquista de Samaria (722-721) a.C.), (a tribo de) Efraim adquiriu uma liderança tão indiscutível, que Efraim e Israel tornaram-se nomes intercambiáveis para o reino do norte. ${ }^{90}$

Sim, desde a divisão do Reino, "Efraim tornou-se a tribo principal do reino do norte, ao ponto em que essa nação nortista chegou a ser intitulada algumas vezes de Efraim". ${ }^{91}$ Ali ficava Samaria, a capital do Reino do Norte. O nome Efraim relembrava a tribo mais famosa, idólatra e pervertida da nação (Os 4,17; 5,3.9.11.13). ${ }^{92}$

\subsection{O pecado leva à ruína (v.15)}

"Provocou a ira Efraim amargamente, seu sangue derramará sobre si, e o seu Senhor trará de volta para ele a sua vergonha" (Os 12,15). Duas palavraschave e uma ideia deste v.15 constam no Pentateuco. A primeira palavra-chave é ספכָ (ele provocou a ira), aparece em Dt 32,16, e como substantivo em Dt 32,19.

A segunda é שוב no hiphil (ele trouxe de volta, ele retribuiu), que também ocorre em Os 12,3c, e consta em Dt 32,41.43, onde, no contexto (v.42), semelhantemente a Os 12,15 , há o derramamento do sangue dos transgressores. Esta noção do castigo divino como justa retribuição pelo pecado dentro do próprio Livro do Profeta Oseias, consta ainda em 9,9.

O verbo "provocou a ira" é usado repetidamente em 1 e 2 Reis para descrever o impacto que a idolatria causou em Deus (1Rs 14,9.15; 15,30 etc.). ${ }^{93}$ E o vocábulo traduzido pelo advérbio "amargamente", que aparece também na profecia de Jeremias ( Jr 6,26; 31,15) trata-se de um substantivo masculino, empregado no plural, para designar "o quão profundamente a conduta deles havia afetado o SENHOR". ${ }^{4}$

\footnotetext{
${ }^{90}$ FEINBERG, C. L., אָּפְרים

${ }^{91}$ CHAMPLIN, R. N., Efraim, p. 292; DIOP, G., The Name "Israel" and Related Expressions in the Books of Amos and Hosea, p. 251-253.

${ }^{92}$ SILVA, C. H., The Literary Structure of Hosea 9-14, p. 445.

${ }^{93}$ MACKAY, J. L., Oseias, p. 354.

94 MACKAY, J. L., Oseias, p. 354.
} 
"Sangue", em Oseias, "é uma referência aos crimes aos quais era aplicada a pena de morte, especialmente os assassinatos (cf. 1.4; 4.2; 6.8)". ${ }^{95} \mathrm{~A}$ ideia presente em Os 12,15 e no Pentateuco é "seu (próprio) sangue derramará sobre si”, repetida diversas vezes pelas expressões nele) e דִִִּיהֶם (o sangue deles estará sobre eles) em Lv 20,9.11.12.13.16.27. O mesmo capítulo 20 de Levítico explica que levar o próprio sangue sobre si representa a pena de morte, num sentido em que o transgressor da Lei de Deus está arcando com as consequências do seu próprio erro (Lv. 20,17.19).

\begin{abstract}
"Culpa de sangue" é um termo que denota um nível de culpa tão grande, por uma ofensa tão severa, que a pena capital é requerida. [...] A culpa de sangue por acidente poderia ser removida (Js 20:1-9). Mas não havia um acidente na culpa de sangue de Israel. Esta culpa de sangue deveria ser deixada, e Israel deveria morrer. ${ }^{96}$
\end{abstract}

O povo é responsabilizado por sua desgraça iminente, juízo que também é pronunciado em Os 4,9. Deus não queria a ruína de seu povo. Sua vontade era a de que o povo se arrependesse e se convertesse. Mas, infelizmente, eles persistiram no pecado e causaram a sua própria tragédia. Derramaram seu próprio sangue sobre si mesmos. $\mathrm{O}$ teor desta mensagem pode ser lida ainda em outro profeta, que tem muitos aspectos em comum com Oseias, Jr 3,39-54.

Outra possibilidade de tradução para o v.15c é: "e sua afronta trará de volta para ele os seus senhores". Em todo o livro de Oseias, Deus nunca é chamado de 'ădonāy, e seria chamado somente aqui. Enquanto que o Tetragrama Sagrado (YHWH) ocorre 45 vezes, 'elohim, 26 vezes, e 'el, 4 vezes,${ }^{97}$ ao contrário de Amós, que emprega 'ădonāy 26 vezes para designar a Deus. ${ }^{98}$ No TM, אִ é usado várias vezes para humanos senhores de escravos (Gn 24,9-10; 39,2-3.7-8; Ex 21,4.6). O sụstantivo pode significar também "afronta", "ofensa" ou "abuso". ${ }^{99}$ Esta outra forma de tradução não entra em desarmonia com a teologia de Oseias, que anuncia um retorno à escravidão no Egito como símbolo do iminente cativeiro assírio (Os 8,13; 9,3.6). Se este for o sentido original desta oração, também está de acordo com a mensagem das duas imediatamente anteriores, neste v.15. Ou seja: a futura

\footnotetext{
${ }^{95}$ MACKAY, J. L., Oseias, p. 354.

${ }^{96}$ STUART, D., Hosea-Jonah, p. 196.

${ }^{97}$ WOLFF, H. W., Hosea, p. XV.

${ }^{98}$ ANDERSEN, F. I.; FREEDMAN, D. N., Hosea, p. 623.

99 DAVIDSON, B., חֶרֶּ, p. p. 276; ALONSO SCHÖKEL, L., 246-247; HOLLADAY, W. L., חֶרֶ, p. 117.
} 
destruição que Deus permitiria recair em breve sobre a nação, viria tão somente em consequência da rebelião do povo.

\subsection{Jacó em Os 12,13: figura positiva ou negativa?}

Está muito longe de haver um consenso entre os intérpretes. Exemplos de especialistas que entendem ser negativa a figura do Patriarca Jacó em Os 12,13: H. W. Wolff, ${ }^{100}$ H. Simian-Yofre, ${ }^{101}$ T. E. McComiskey, ${ }^{102}$ M. L. C. Lima, ${ }^{103}$ L. Alonso Schökel e J. L. Sicre Diaz, ${ }^{104}$ C. S. Jiménez, ${ }^{105}$ F. D. Nichol ${ }^{106}$ E. J. Pentiuc, ${ }^{107}$ J. van Ruiten ${ }^{108}$ e J. L. Mackay. ${ }^{109}$ Exemplos daqueles que entendem que ela seja positiva: M. A. Sweeney, ${ }_{110}$ D. Stuart, ${ }^{111}$ D. A. Hubbard, ${ }^{112}$ T. E. Fretheim, ${ }^{113}$ B. H. Lim $^{114}$ e M. I. Gruber. ${ }^{115}$ Não obstante Lim tenha a compreensão de que a visão de Os 12,13 sobre Jacó seja positiva, ele pondera que, em realidade, a tradição do patriarca no cap. 12 de Oseias como um todo é ambígua no que diz respeito à moral dele. ${ }^{116} \mathrm{O}$ comentador observa: "a narrativa de Jacó demonstra que a estrada da reconciliação, com seus zigue-zagues, envolve encontros desesperados e descobertas que não podem ser antecipados a princípio. Tal imprevisibilidade deve ser esperada quando seres humanos buscam ser reconciliados com um Deus santo e amoroso". ${ }^{117}$

\footnotetext{
${ }^{100}$ WOLFF, H. W., Hosea, p. 216.

101 SIMIAN-YOFRE, H., El Deserto de los Dioses, p. 159-160.

${ }^{102}$ MCCOMISKEY, T. E., The Minor Prophets, p. 210.

${ }^{103}$ LIMA, M. L. C., Hesed nos Escritos de Oseias, p. 243.

${ }^{104}$ ALONSO SCHÖKEL, L.; SICRE DIAZ, J. L., Profetas II, p. 944.

105 JIMÉNEZ, C. S., El Desierto en el Profeta Oseas, p. 176-179.

${ }^{106}$ NICHOL, F. D., Isaías a Malaquias, p. 1024.

${ }^{107}$ PENTIUC, E. J., Long-Suffering Love, p. 358. the Targum of Hosea 12, p. 595, 596-600, 607-612).

${ }^{109}$ MACKAY, J. L., Oseias, p. 352-353.

${ }^{110}$ SWEENEY, M. A., The Twelve Prophets, p. 127-128.

${ }^{111}$ STUART, D., Hosea-Jonah, p. 197.

${ }^{112}$ HUBBARD, D. A., Oseias, p. 223-224.

${ }^{113}$ FRETHEIM, T. E., Reading Hosea-Micah, p. 72-73.

114 LIM, B. H., Hosea 11:12-13:16 (12:1-14:1), p. 204.

115 GRUBER, M. I., Hosea, p. 518-519.

${ }^{116}$ LIM, B. H., Hosea 11:12-13:16 (12:1-14:1), p. 203.

${ }^{117}$ LIM, B. H., Hosea 11:12-13:16 (12:1-14:1), p. 202-203.
}

${ }^{108}$ VAN RUITEN, J., The Image of Jacob in the Targum of Hosea 12, p. 595, 596, 604-607, 612. Em seu artigo, Van Ruiten analisa uma versão deste texto de Os 12, o Targum de Jônatas, que tentou "melhorar" a imagem de Jacó, aquela que consta no TM, tornando-a totalmente positiva, como um exemplo de conduta para o povo de Israel (VAN RUITEN, J., The Image of Jacob in 
De fato, uma leitura atenta e imparcial dos ciclos de Jacó em Gn 25,19$37,1 \mathrm{ab}$ e em Os 12,4-5.13, nos revela que, em nenhum dos dois relatos, o patriarca aparece numa perspectiva extrema, seja como vilão, seja como herói. Em vez disso, o que se tem é o retrato de um pecador, que engana seu irmão (Os 12,4a), tem seu conflito com Deus (Os 12,4b-5d) e um encontro com ele, onde recebe sua revelação (Os 12,5ef). Lim comenta: "Jacó permanece como símbolo de ambos: juízo e salvação. A beleza das narrativas bíblicas está na maneira em que elas repetidamente demonstram como Deus pode redimir pessoas profundamente defeituosas, e usá-las como um meio de abençoar outras". ${ }^{118}$ Sweeney diz: "Na visão do profeta (Oseias), se Jacó poderia mudar, então o Israel do Norte também poderia". ${ }^{119}$

Seguindo esta mesma linha de raciocínio, Diop argumenta que o Profeta Oseias usa Jacó como um exemplo negativo, por causa de seus métodos não ortodoxos; mas também como um exemplo positivo, por causa de seu arrependimento e subsequente bênção de ter encontrado a Deus. ${ }^{120}$ Nisto havia

Uma revelação da possível mudança dos destinos da corrente comunitária de apostasia - se eles progredissem para a segunda fase da vida do patriarca. Em outras palavras, se eles se arrependessem conforme o pedido do v.6 do mesmo capítulo [...] então eles receberiam as mesmas bênçãos de Jacó. O chamado é, necessariamente, para a reorientação da vida inteira para Deus, marcada por uma total dependência dele. ${ }^{121}$

O v.13 não deixa claro se a visão que o profeta tem de Jacó, neste ponto específico, é positiva ou negativa. A fuga para o campo de Aram (v.13a) certamente foi algo negativo, como uma consequência de sua mentira. Mas o fato de ter servido por uma mulher e ter guardado um rebanho por amor a ela

${ }^{118}$ LIM, B. H., Hosea 11:12-13:16 (12:1-14:1), p. 210. Diop chama atenção para o fato de que esta justaposição ou este entrelaçamento inseparável entre oráculos de juízo e salvação é uma característica que permeia todo o Livro de Oseias, fazendo parte de sua complexidade, singularidade e da essência de sua mensagem (DIOP, G., The Name "Israel" and Related Expressions in the Books of Amos and Hosea, p. 240-242). "O uso da linguagem figurativa indica que seu teor básico é indicar a intenção de Deus em relação a ambos, juízo e salvação" (DIOP, G., The Name "Israel" and Related Expressions in the Books of Amos and Hosea, p. 241). Wyrtzen divide o Livro de Oseias em cinco ciclos de juízo-salvação, que no TM ficam delimitados assim: 1,2-2,3; 2,4-25; 3,1-5; 4,4-11,11; 12,1-14,9 (WYRTZEN, D. B., The Theological Center of the Book of Hosea, p. 316).

119 SWEENEY, M. A., The Twelve Prophets, p. 110.

${ }^{120}$ DIOP, G., The Name "Israel" and Related Expressions in the Books of Amos and Hosea, p. 292.

${ }^{121}$ DIOP, G., The Name "Israel” and Related Expressions in the Books of Amos and Hosea, p. 292. 
(v.13bc) não é algo necessariamente negativo. Se for negativo, o entendimento é que Jacó se submeteu à escravidão por mera paixão carnal. Contudo, se o prisma for positivo, então a interpretação é que o patriarca amava tanto sua futura esposa ao ponto de se fazer um escravo por ela. Caso o v.13bc tenha um sentido negativo, a sua tradução com o v.14 pode ser assim: "serviu Israel por uma mulher, e por uma mulher ele guardou (um rebanho). Mas, por um profeta YHWH fez subir Israel do Egito; e por um profeta ele foi guardado". Ou seja, um contraste entre a atitude de Israel e a de YHWH. Caso a perspectiva seja positiva, então a tradução poderia ficar desta maneira: "serviu Israel por uma mulher, e por uma mulher ele guardou (um rebanho). Assim, por um profeta YHWH fez subir Israel do Egito; e por um profeta ele foi guardado". Ou seja, a atitude de YHWH seria semelhante à de Jacó no servir e guardar. Sabendo-se que, tanto para a interpretação negativa quanto para a positiva, o valor da mulher no v.13bc é motivacional, e o do profeta no v.14 é instrumental.

\section{6. "E por um profeta ele foi guardado" (v.14b)}

A conexão do êxodo do Egito com os profetas (e Moisés) pode ser vista também em Am 2,10-12 e Mq 6,4. A maioria dos comentadores concorda que este profeta, mencionado aqui em Os 12,14, seja Moisés, ${ }^{122}$ o mesmo libertador que é retratado no Pentateuco como aquele que foi usado pelo Senhor para conduzir o povo eleito da escravidão para a terra prometida.

No entanto, alguns enxergam na frase "Por um profeta YHWH fez subir Israel do Egito, e por um profeta ele foi guardado", dois profetas: o primeiro, que conduziu o povo para fora do Egito, seria Moisés; e o segundo, aquele que guiou o povo em Canaã, seria Samuel. ${ }^{123}$ Porém, como há um paralelismo sinônimo entre as partes a e b do v.14, é mais acertado concluir que o mesmo profeta de 14a seria o de 14b. Além disso, a dedução de que Oseias está se referindo a Moisés está explícita pela tradição do êxodo, e pelo fato de Moisés

122 WOLFF, H. W., Hosea, p. 216; STUART, D., Hosea-Jonah, p. 195; MCCOMISKEY, T. E., The Minor Prophets, p. 210-211; SWEENEY, M. A., The Twelve Prophets, p. 128; ALONSO SCHÖKEL, L.; SICRE DIAZ, J. L., Profetas II, p. 944; NICHOL, F. D., Isaías a Malaquias, p. 1024; SILVA, C. H., The Literary Structure of Hosea 9-14, p. 446; LIMA, M. L. C., O Livro de Oseias e sua Leitura das Tradições do Exodo-Deserto, p. 314-315; RAMIREZ, F. F. L., Are the Allusions to Jacob and Moses in Hosea 12 Late Insertions?, p. 121; FRETHEIM, T. E., Reading Hosea-Micah, p. 73; VAN RUITEN, J., The Image of Jacob in the Targum of Hosea 12, p. 606; PENTIUC, E. J., Long-Suffering Love, p. 359; JIMÉNEZ, C. S., El Desierto en el Profeta Oseas, p. 179-181; DEARMAN, J. A., The Book of Hosea, p. 314; GRUBER, M. I., Hosea, p. 518-519. ${ }^{123}$ ANDERSEN, F. I.; FREEDMAN, D. N., Hosea, p. 621; HUBBARD, D. A., Oseias, p. 224; MACKAY, J. L., Oseias, p. 353. 
ser considerado o grande profeta da história de Israel (Nm 12,6-8; Dt 18,15-19; 34,8-12; Sl 103,7; 105,26; Is 10,11-14; Lc 16,29.31; 24,27.44; Jo 5,46-47; At $15,21)$. Já quanto a Samuel, não há clareza, parecendo mesmo só mera especulação. Se forem dois profetas referidos em Os 12,14, então o segundo poderia ser qualquer um entre Moisés e Oseias, como Natã (2Sm 7,1-4.17; 12,1.7.13-15; 1Rs 1,22-24.32.38), Gad (1Sm 22,5; 2Sm 24,11-14), Ido (2Cr 9,29; 13,22), Elias (1Rs 17,1-2Rs 1,18), Eliseu (2Rs 2,19-13,21), Miqueias (1Rs 22,5-28) ou ainda outros anônimos (1Rs 13,1-32).

O verbo שָׁמָר (ele guardou), empregado para descrever o cuidado de Deus por seu povo, é o mesmo empregado para tratar da obediência que Israel devia a YHWH no contexto da aliança (Ex 19,3-5; Dt 28,1.9.13). Ou seja, nos termos da aliança entre YHWH e Israel, o primeiro guardava seu povo no sentido de proteger, guiar e cuidar dele desde a peregrinação no deserto (Dt 8,4;29,4; Ne 9,19-21), e o segundo deveria, numa resposta de amor, praticar os mandamentos deste Deus carinhoso.

Chama a atenção que Moisés não seja mencionado por seu nome, mas sim por sua função. Por que seu nome foi omitido? Acontece que Oseias não está preocupado em dar uma informação detalhada acerca das tradições do êxodo e de Moisés, mas destacar a função profética, para mostrar que esta era a única mediação confiável naquele momento. ${ }^{124}$ Ao ler-se o contexto imediato (Os 12,11), fica mais claro que a ênfase desta passagem não se concentra na pessoa do profeta, mas no ministério profético; "parece valer mais para o texto a função do que o personagem individual". ${ }^{125}$ Consequentemente, isto se relacionava também com o ofício profético de Oseias, o qual sofria para exercêlo (Os 9,7-9). E este dom de profecia era uma forma de YHWH continuar guardando o seu povo. ${ }^{126} \mathrm{Em} 2 \mathrm{Cr} 20,20$ está escrito que aqueles que confiam em YHWH e em seus profetas estarão seguros e prosperarão. O Livro do Apocalipse $(12,17$ e 19,10) apresenta o dom profético como um testemunho da própria pessoa de Jesus Cristo. A ocultação do nome do profeta em Os 12,14 serve para indicar ao leitor ainda que, na história do êxodo, Moisés foi um instrumento, mas o verdadeiro protagonista foi Deus.

\footnotetext{
124 JIMÉNEZ, C. S., El Desierto en el Profeta Oseas, p. 179.

${ }^{125}$ LIMA, M. L. C., O Livro de Oseias e sua Leitura das Tradições do Êxodo-Deserto, p. 315.

${ }^{126}$ SWEENEY, M. A., The Twelve Prophets, p. 128.
} 


\section{Conclusão}

Na condenação de Galaad e Guilgal, registrada em Os 12,12, a denúncia é feita contra um culto que se tornou nulo e vazio, pelo fato de os adoradores viverem em iniquidade. No AT, há um outro livro profético cuja mensagem adverte muito sobre esta incoerência: Isaías (1,10-17; 58,3-12). A síntese deste raciocínio, que expressa de maneira clara e objetiva o sentimento de Deus para com o falso culto, encontra-se em Is 1,13c: "não suporto iniquidade e solenidade". O NT também condena a religiosidade destituída da caridade, bem como o seguimento de uma tradição religiosa desassociado da observância dos princípios divinos em sua essência (Mt 23,23; Mc 7,8-13; 2Tm 3,5). Citando o próprio Profeta Oseias $(6,6)$, Jesus Cristo alerta: "quero misericórdia e não sacrifício" (Mt 12,7). A maioria das religiões da Antiguidade se concentrava em rituais e artes mágicas. Mas é interessante que, no Livro do Êxodo, os preceitos morais vêm antes da regulamentação ritual (Ex 20,1-23,33; 25,140,38). Que lição maravilhosa há aqui para os religiosos de hoje! Que impacto haveria na sociedade secular, se aqueles que professam uma fé atentassem mais para sua conduta para com Deus e o próximo, do que para as práticas litúrgicas!

No que tange à exegese do cap. 12 do Livro de Oseias, ela traz a lume um dado precioso para a pesquisa do Pentateuco: as tradições das origens genealógica e vocacional do povo de Israel já coexistiam, pelo menos no Reino do Norte, há aproximadamente trezentos anos antes do período que até o momento vem sendo apresentado pela crítica histórica da Bíblia (séc. V a.C.).

Outrossim, há ali dois personagens marcantes destas duas tradições de origem: da genealógica, Jacó (Os 12,4-5.13); da vocacional, Moisés (Os 12,14). Segundo as Escrituras, ambos tiveram um passado manchado pelo pecado (Gn 25,29-34; 27,1-45; Ex 2,11-14), fugiram em consequência dele (Gn 28,5; Ex 2,15), foram encontrados por Deus (Gn 28,10-15; 32,2-3.23-27; Ex 3,1-4,17) e assim receberam uma transformação de vida (Gn 28,16-22; 32,28-31; Ex 4,275,3). Como disse certa vez o Cardeal Van Thuan: "Não há pecador sem passado, nem santo sem futuro". Pelo estudo de Os 12, pode-se compreender que o grande ator ali não é, nem Jacó, nem Moisés, mas YHWH, que aparece como aquele que é capaz de redimir qualquer ser humano, e consequentemente, qualquer sociedade.

Os 12,15 ensina que o pecado contém a semente da destruição. Esta é uma lição recorrente na Sagrada Escritura (Lm 3,39; Gl 6,7-8). Na agricultura há uma lei natural fixa da semeadura e da colheita. Neste processo, há dois aspectos que se destacam: a) sempre se colhe o que se planta, e b) o produto 
colhido sempre é bem maior do que aquele que foi plantado, ainda que contenha a mesma essência e seja da mesma natureza. Mediante esta observação, podemos depreender que nossas atitudes sempre terão consequências: as de caridade sempre voltarão para nós, e de forma multiplicada (Lc 6,38); de igual modo, as de perversidade, sempre voltarão, e de maneira multiplicada também, para quem as pratica. Mas Deus não tem prazer na morte de ninguém, e é sua vontade que todos se arrependam e assim possam ser salvos (Ez 18,23.31-32; 31,11; Jo 3,17; 1Tm 2,3-4; 2Pe 3,9). Mesmo quando merecida, a obra da destruição é estranha ao Senhor (Is 28,21). "De fato, as retribuições do pecado são a morte, mas o dom de Deus é a vida eterna em Cristo Jesus, o nosso Senhor". (Rm 3,23). Quando contemplamos o infinito amor de Deus, como se encontra retratado na Sagrada Escritura e no sacrifício de Cristo, só podemos chegar a uma conclusão honesta: É muito mais fácil ser salvo do que se perder.

Quanto à perspectiva da figura de Jacó em Os 12,13bc, se é positiva ou negativa, não conseguimos chegar à uma conclusão pelo presente estudo, ficando o desafio para outros pesquisadores que se seguirão. Assim sendo, oferecemos, a nível de consideração final, as duas possibilidades de interpretação e aplicação teológica-pastoral. Se Jacó ali for uma figura negativa, então sua atitude é apresentada à sua posteridade como a de um homem que se vendeu à escravidão por uma mera paixão carnal; o que representaria o futuro da nação de Israel: seriam levados para o cativeiro por causa da sua desobediência à palavra de YHWH. Esta forma de proceder estava em claro contraste com o procedimento de $\mathrm{YHWH}$, que os guardara e continuava a guardá-los através do dom de profecia.

Porém, se a visão que Oseias quis passar a respeito de Jacó for positiva, então sua atitude é posta como uma analogia da ação de Deus. Ou seja, assim como Jacó amou sua esposa a ponto de se humilhar e servir para ter o direito de possuí-la, de certa forma, comprando-a; assim também o Senhor comprou a sua esposa, que é o seu povo, redimindo-o. Conquanto não seja possível determinar que esta foi a intenção original do autor, esta interpretação está em harmonia com a mensagem do Livro de Oseias $(3,1-5)$; assim como também com o ensino do NT, onde Jesus Cristo é o esposo da igreja, o esposo que se humilha ao ponto da escravidão para compra-la e remi-la com seu próprio sangue, isto é, com sua vida (Mc 10,45; Ef 5,25-27; Fp 2,5-11).

É digno de nota que os dois personagens aludidos em Os 12,13-14, Jacó e Moisés, foram pastores do rebanho de seus sogros (Gn 30,31.36; Ex 3,1), e a atividade deles aqui está num nítido paralelo de um com o outro. Mesmo do ponto de vista negativo, a ação de "guardar", praticada por Jacó em seu trabalho 
pastoril, é posta como a mesma ação de Deus em "guardar" as suas ovelhas, ou o seu povo, por meio do seu profeta. No S1 121 vemos que YHWH é o Deus que guarda os seus filhos. A imagem de YHWH como um pastor também está de acordo com outras partes de Oseias $(4,16$ e 10,11) e da Bíblia Sagrada como um todo (S1 23,1; 119,176; Lc 15,3-7; $1 \mathrm{Pd} 2,25 ; 5,4)$. Mas é na aplicação que Jesus faz desta ilustração, que ela encontra o seu pleno significado. Ele se apresenta a nós como o Bom Pastor, que ama tanto as suas ovelhas, a ponto de entregar sua vida por amor a elas (Jo 10,11-18). Sim, ele as guarda com seu próprio sangue! Nesta parábola de um pastor que morre no lugar das suas ovelhas, encontra-se novamente o caráter vicário do mistério da paixão de Cristo, onde o Filho de Deus se rende para resgatar a humanidade pecadora. Esta é a mensagem do Profeta Oseias: o Senhor é o Marido e o Pastor que se doa para resgatar sua esposa e suas ovelhas.

\section{Referências bibliográficas}

ALONSO SCHÖKEL, L. אוֹן In: ALONSO SCHÖKEL, L. Dicionário Bíblico Hebraico-Português. São Paulo: Paulus, 1997. p. 33.

ALONSO SCHÖKEL, L. אָּ In: ALONSO SCHÖKEL, L. Dicionário Bíblico Hebraico-Português. São Paulo: Paulus, 1997. p. 34.

ALONSO SCHÖKEL, L. אִ. In: ALONSO SCHÖKEL, L. Dicionário Bíblico Hebraico-Português. São Paulo: Paulus, 1997. p. 60.

ALONSO SCHÖKEL, Lג גֵּ In: ALONSO SCHÖKEL, L. Dicionário Bíblico Hebraico-Português. São Paulo: Paulus, 1997. p. 138.

ALONSO SCHÖKEL, L. חרֶֶ. In: ALONSO SCHÖKEL, L. Dicionário Bíblico Hebraico-Português. São Paulo: Paulus, 1997. p. 246-247.

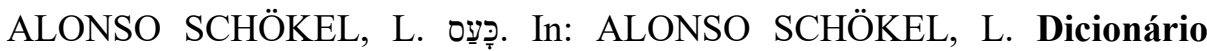
Bíblico Hebraico-Português. São Paulo: Paulus, 1997. p. 323.

ALONSO SCHÖKEL, L. רוד. In: ALONSO SCHÖKEL, L. Dicionário Bíblico Hebraico-Português. São Paulo: Paulus, 1997. p. 608.

ALONSO SCHÖKEL, L. שָָָׁ In: ALONSO SCHÖKEL, L. Dicionário Bíblico Hebraico-Português. São Paulo: Paulus, 1997. p. 637.

ALONSO SCHÖKEL, L. שֵֶׁ In: ALONSO SCHÖKEL, L. Dicionário Bíblico Hebraico-Português. São Paulo: Paulus, 1997. p. 659. 


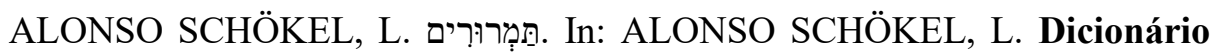
Bíblico Hebraico-Português. São Paulo: Paulus, 1997. p. 705.

ALONSO SHÖKEL, L.; SICRE DIAZ, J. L. Profetas II: Ezequiel - Doze Profetas Menores - Daniel - Baruc - Carta de Jeremias. São Paulo: Paulus, 1991.

ANDERSEN, F. I.; FREEDMAN, D. N. Hosea: a new translation with introduction and commentary. New Haven, Londres: Yale University Press, 2008. v.XXIV.

BÍBLIA Hebraica Stuttgartensia. 5. ed. Stuttgart, Alemanha: Deutsche Bibel Gesellschaft, 1997.

BÍBLIA Sagrada, Almeida Revista e Atualizada. 2. ed. Barueri, SP: Sociedade Bíblica do Brasil, 2018.

BÍBLIA Sagrada, Nova Almeida Atualizada. Barueri, SP: Sociedade Bíblica do Brasil, 2017.

BÍBLIA Sagrada, Nova Versão Internacional. Barueri, SP: Sociedade Bíblica do Brasil, 2011.

BÍBLIA Sagrada, Tradução Oficial da CNBB. 3. ed. Brasília, DF: Confederação Nacional dos Bispos do Brasil, 2019.

BÍBLIA Tradução Ecumênica. São Paulo: Edições Loyola, 2020.

CHAMPLIN, R. N. Efraim. In: CHAMPLIN, R. N. Enciclopédia de Bíblia, Teologia e Filosofia. São Paulo: Hagnos, 2013. v. 2. p. 292.

CHAMPLIN, R. N. Gileade. In: CHAMPLIN, R. N. Enciclopédia de Bíblia, Teologia e Filosofia. São Paulo: Hagnos, 2013. v. 2. p. 906-907.

CHAMPLIN, R. N. Gilgal. In: CHAMPLIN, R. N. Enciclopédia de Bíblia, Teologia e Filosofia. São Paulo: Hagnos, 2013. v. 2. p. 907.

DAVIDSON, B. אָּוּ In: DAVIDSON, B. The Analytical Hebrew and Chaldee Lexicon. Peabody, MA: Hendrickson Publishers, 2006. p. 13.

DAVIDSON, B. גֵ. In: DAVIDSON, B. The Analytical Hebrew and Chaldee Lexicon. Peabody, MA: Hendrickson Publishers, 2006. p. 138.

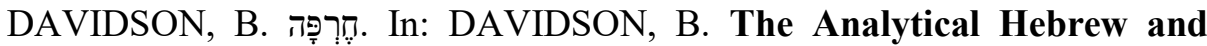
Chaldee Lexicon. Peabody, MA: Hendrickson Publishers, 2006. p. 276. 
DAVIDSON, B. Tִָּּ. In: DAVIDSON, B. The Analytical Hebrew and Chaldee Lexicon. Peabody, MA: Hendrickson Publishers, 2006. p. 389.

DAVIDSON, B. רוד. In: DAVIDSON, B. The Analytical Hebrew and Chaldee Lexicon. Peabody, MA: Hendrickson Publishers, 2006. p. 677.

DAVIDSON, B. שָׁ. In: DAVIDSON, B. The Analytical Hebrew and Chaldee Lexicon. Peabody, MA: Hendrickson Publishers, 2006. p. 702.

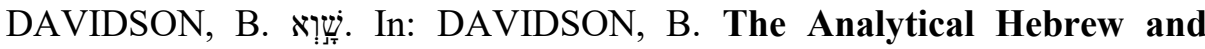
Chaldee Lexicon. Peabody, MA: Hendrickson Publishers, 2006. p. 703.

DEARMAN, J. A. The Book of Hosea. Grand Rapids, MI: William B. Eerdmans Publishing Company, 2010.

DEL BARCO DEL BARCO, F. J. Sintaxes Verbal en los Profetas Menores Preexílicos. Madrid, 2001, 368p. Tese. Facultad de Filología, Universidad de Madrid.

DIOP, G. The Name "Israel" and Related Expressions in the Books of Amos and Hosea. Berrien Springs, MI, 1995. 433p. Tese. Seventh-day Adventist Theological Seminary, Andrews University. Disponível em: $<$ https://digitalcommons.andrews.edu/cgi/viewcontent.cgi?article=1034\&cont ext=dissertations $>$. Acesso em: 08 fev. 2021.

FEINBERG, C. L. אֶפְרבים. In: HARRIS, R. L.; ARCHER JR., G.; WALTKE, B. K. Dicionário Internacional de Teologia do Antigo Testamento. São Paulo: Sociedade Religiosa Edições Vida Nova, 1998. p. 111.

FRETHEIM, T. E. Reading Hosea-Micah: a literary and theological commentary. Macon, Georgia: Smyth \& Helwys Publishing, Inc., 2013.

GRUBER, M. I. Hosea: a textual commentary. Londres / Nova York: Bloomsbury T\&T Clark, 2017.

HOLladAY, W. L. אוןן. In: HOLLADAY, W. L. Léxico Hebraico e Aramaico do Antigo Testamento. São Paulo: Sociedade Religiosa Edições Vida Nova, 2010. p. 81.

HOLLADAY, W. L. חִרִּפ In: HOLLADAY, W. L. Léxico Hebraico e Aramaico do Antigo Testamento. São Paulo: Sociedade Religiosa Edições Vida Nova, 2010. p. 117. 
HOLLADAY, W. L. כָָּ In: HOLLADAY, W. L. Léxico Hebraico e Aramaico do Antigo Testamento. São Paulo: Sociedade Religiosa Edições Vida Nova, 2010. p. 229.

HOLLADAY, W. רוד. In: HOLLADAY, W. L. Léxico Hebraico e Aramaico do Antigo Testamento. São Paulo: Sociedade Religiosa Edições Vida Nova, 2010. p. 475.

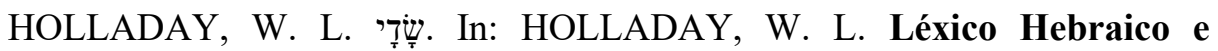
Aramaico do Antigo Testamento. São Paulo: Sociedade Religiosa Edições Vida Nova, 2010. p. 496.

HUBBARD, D. A. Oseias: introdução e comentário. São Paulo: Sociedade Religiosa Edições Vida Nova, 2011.

JIMENEZ, C. S. EI Desierto en el Profeta Oseas. Estella (Navarra), Espanha: Editorial Verbo Divino, 2006.

KALLAND, E. S. לִִּ In: HARRIS, R. L.; ARCHER JR., G.; WALTKE, B. K. Dicionário Internacional de Teologia do Antigo Testamento. São Paulo: Sociedade Religiosa Edições Vida Nova, 1998. p. 270-271.

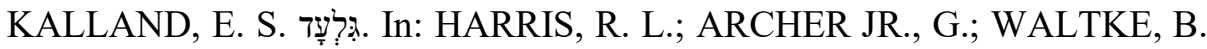
K. Dicionário Internacional de Teologia do Antigo Testamento. São Paulo: Sociedade Religiosa Edições Vida Nova, 1998. p. 272-273.

LIM, B. H. Hosea 11:12-13:16 912:1-14:1). In: LIM, B. H.; CASTELO, D. Hosea. Grand Rapids, MI; Cambridge, Reino Unido: William B. Eerdmans Publishing Company, 2015.

LIMA, M. L. C. Hesed nos Escritos de Oseias: significado e valor teológico elementos para a história e evolução de um conceito bíblico. Rio de Janeiro, 1990. 288p. Dissertação. Faculdade de Teologia, Pontifícia Universidade Católica do Rio de Janeiro. v.1.

LIMA, M. L. C. O Livro de Oseias e sua Leitura das Tradições do ÊxodoDeserto. Revista de Cultura Teológica, v. 25, n. 28, p. 295-327, jul./dez. 2016. Disponível em: <https://revistas.pucsp.br/culturateo/article/view/rct.i88.30935>. Acesso em: 28 out. 2019.

MACKAY, J. L. Oseias. São Paulo: Editora Cultura Cristã, 2015. 
MARTENS, E. A. רוד. In: VANGEMEREN, W. A. (Org.). Novo Dicionário Internacional de Teologia e Exegese do Antigo Testamento. São Paulo: Editora Cultura Cristã, 2011. v. 3. p. 1603-1604.

MCCOMISKEY, T. E. The Minor Prophets: an exegetical and expository commentary. Grand Rapids, MI: Baker Book House, 1992. v.1.

NICHOL, F. D. Isaías a Malaquias. In: NICHOL, F. D. (Ed.). Comentário Bíblico Adventista do Sétimo Dia. Tatuí, SP: Casa Publicadora Brasileira, 2013.

PENTIUC, E. J. Long-Suffering Love: a commentary on Hosea with patristic annotations. Brookline, MA: Holy Cross Orthodox Press, 2008.

RAMIREZ, F. F. L. Are the Allusions to Jacob and Moses in Hosea 12 Late Insertions? Landas, v. 29, n. 2, p. 119-143, 2015. Disponível em: $<$ https://journals.ateneo.edu/ojs/index.php/landas/issue/archive $>$. Acesso em: 14 nov. 2019.

RENDSBUIRG, G. A. Linguistic Variation and the Foreign Factor in the Hebrew Bible. In: IZRE'EL, S.; RINA, D. (Eds.). Israel Oriental Studies XV: language and culture in the near east. Leiden, Holanda: E. J. Brill, 1995. p. 177-180.

RENDSBUIRG, G. A. A Comprehensive Guide to the Israelian Hebrew: grammar and lexicon. Oriente, v. 38, p. 5-35, 2003. Disponível em: $<$ https://www.jstage.jst.go.jp/article/orient1960/38/0/38_0_5/_article>. Acesso em: 05 nov. 2019.

RÖMER, T. Oseias. In: RÖMER, T.; MACCHI, J. D.; NIHAN, C. (Orgs.). Antigo Testamento: história, escritura e teologia. São Paulo: Edições Loyola, 2010. p. 465-483.

SEPTUAGINTA. Stuttgart, Alemanha: Deutsche Bibel Gesellschaft, 2006; Barueri, SP: Sociedade Bíblica do Brasil, 2011.

SILVA, C. H. The Literary Structure of Hosea 9-14. Bibliotheca Sacra, n. 164, p. 435-453, out./dez. 2007. Disponível em: $<$ http://eds.a.ebscohost.com/eds/pdfviewer/pdfviewer?vid=8\&sid=17e9484d3c2c-4f74-a8e2-c92b8df97ace\%40sessionmgr4007>. Acesso em: 28 out. 2019.

SIMIAN-YOFRE, H. EI Deserto de los Dioses: teología e historia en el libro de Oseas. Madrid: Ediciones El Almendro de Cordoba, S. L., 1993.

SWEEnWEy, M. A. The Twelve Prophets: Hosea, Joel, Amos, Obadiah, Jonah. Collegiville, Minnesota: The Liturgical Press, 2000. 
STUART, D. Hosea-Jonah. In: HUBBARD, D. A.; BARKER, G. W. Word Biblical Commentary. Dallas, Texas: Publisher Word Books, 1987. v. 31.

VAN RUITEN, J. The Image of Jacob in the Targum of Hosea 12. Journal for the Study of Judaism, n. 43, p. 592-612, 2012. Disponível em: $<$ http://eds.b.ebscohost.com/eds/pdfviewer/pdfviewer?vid=6\&sid=e3f0128be504-43be-be4e-2d2047f337bd\%40pdc-v-sessmgr05>. Acesso em: 02 fev. 2021.

WHITE, W. רוד. In: HARRIS, R. L.; ARCHER JR., G.; WALTKE, B. K. Dicionário Internacional de Teologia do Antigo Testamento. São Paulo: Sociedade Religiosa Edições Vida Nova, 1998. p. 1405.

WOLFF, H. W. Hosea: a commentary on the book of the prophet Hosea. Filadélfia: Fortress Press, 1989.

WYRTZEN, D. B. The Theological Center of the Book of Hosea. Bibliotheca Sacra, v. 141, n. 564, p. 315-329, out./dez. 1984. Disponível em: $<$ http://eds.b.ebscohost.com/eds/pdfviewer/pdfviewer?vid=1\&sid=24344244ef81-497e-8ee5-ebcf5ae9c311\%40sessionmgr101>. Acesso em: 08 fev. 2021.

\section{Ygor Almeida de Carvalho Silva}

Mestre em Teologia Bíblica pela Pontifícia Universidade Católica do Rio de Janeiro

Rio de Janeiro / RJ - Brasil E-mail: ygor.adv@hotmail.com

Recebido em: 16/02/2021

Aprovado em: 28/09/2021 